NBER WORKING PAPER SERIES

\title{
STRATEGIES FOR CONTROLLING INFLATION
}

Frederic S. Mishkin

Working Paper 6122

\section{NATIONAL BUREAU OF ECONOMIC RESEARCH 1050 Massachusetts Avenue \\ Cambridge, MA 02138}

August 1997

This paper has been prepared for the Reserve Bank of Australia's 1997 Conference on Monetary Policy and Inflation Targeting, H.C. Coombs Centre, Kirribilli, Australia, July 21-22, 1997. I thank Dorothy Sobol for her comments. Any views expressed in this paper are those of the author only and not those of the National Bureau of Economic Research, Columbia University, the Federal Reserve Bank of New York, or the Federal Reserve System. This paper is part of NBER's research programs in Economic Fluctuations and Growth and Monetary Economics.

(C) 1997 by Frederic S. Mishkin. All rights reserved. Short sections of text, not to exceed two paragraphs, may be quoted without explicit permission provided that full credit, including $\mathbb{C}$ notice, is given to the source. 
Strategies for Controlling Inflation

Frederic S. Mishkin

NBER Working Paper No. 6122

August 1997

JEL No. E5

Economic Fluctuations and Growth

and Monetary Economics

\section{ABSTRACT}

This paper examines what strategies policymakers have used to both reduce and control inflation. It first outlines why a consensus has emerged that inflation needs to be controlled. Then it examines four basic strategies: exchange rate pegging, monetary targeting, inflation targeting, and the "just do it" strategy of preemptive monetary policy with no explicit nominal anchor. The discussion highlights the advantages and disadvantages of each strategy and sheds light not only on how disinflation might best be achieved, but also on how hard won gains in lowering inflation can be locked in.

Frederic S. Mishkin

Federal Reserve Bank of New York

33 Liberty Street

New York, NY 10045

and NBER

frederic.mishkin@frbny.sprint.com 


\section{I. \\ Introduction}

In the last fifteen years, an extraordinary development has occurred in economies throughout the world: Inflation has fallen dramatically, in many industrialized as well as emerging market countries, to the point where many of them have reached what might arguably be called price stability. Why did this happen and how did policymakers achieve this feat?

This paper examines these questions by first outlining why a consensus has emerged that inflation needs to be controlled. Then it examines different strategies for controlling inflation and highlights the advantages and disadvantages of these different strategies. The discussion should shed light not only on how disinflation might best be achieved, but also on how the hardwon gains in lowering inflation can be locked in, so that inflation is less likely to rear its ugly head in the future.

\section{II. The Growing Consensus for Inflation Reduction}

An important reason why so many countries have reduced their inflation rates in recent years is that there has been a growing consensus, particularly among central bankers and even in the public at large, that inflation reduction and price stability should be the primary or overriding long-term goal of monetary policy. This consensus has emerged from economic research and actual economic events over the last thirty years, as is discussed in this section.

The rationale for pursuing price stability as the primary long-term goal for monetary policy rests on two basic propositions: First is that the activist monetary policy to reduce unemployment in the short run might be undesirable because it can lead to higher inflation but not lower unemployment. Second is that price stability in the long run promotes a higher level of economic output and more rapid economic growth. The corollary of these two propositions is that price stability is the appropriate overriding, long-run goal of monetary policy because it 
will produce better economic outcomes.

\section{The Case Against Monetary Policy Activism}

Thirty years ago, both the public and the majority of the economics profession supported a so-called activist monetary policy: i.e., the taking of active steps to reduce unemployment with expansionary monetary policy whenever unemployment rose above a "full-employment level." In the 1960s this level was defined to be around $4 \%$ in the United States. Support for activism was based on two principles. First was that macroeconometric models, particularly large ones with many equations, had become sufficiently advanced to accurately predict the impact of changes in both monetary and fiscal policy on the aggregate economy. Thus, manipulation of monetary and fiscal policy levers could be used to dampen fluctuations in the business cycle.

The second principle supporting an activist monetary policy was popularized by Paul Samuelson and Robert Solow in their famous paper in 1960 (Samuelson and Solow [1960]) that there was a long-run Phillips curve tradeoff which could be exploited. A simple linear version of this Phillips curve can be written as follows:

$$
\pi_{\mathrm{t}}=\mathrm{k}-\alpha\left(\mathrm{U}_{\mathrm{t}}-\mathrm{U}_{\mathrm{t}}^{\mathrm{n}}\right)
$$

where,

$$
\begin{aligned}
& \pi_{\mathrm{t}}=\text { inflation at time } \mathrm{t} \text {. } \\
& \mathbf{k}=\text { constant. } \\
& \alpha=\text { the slope of the Phillips curve, i.e, how much inflation changes for a } \\
& \text { given change in } U_{t}-U_{t}^{n} \text {. } \\
& U_{t}=\text { unemployment rate at time } t \text {. } \\
& U_{t}^{n}=\text { natural rate of unemployment at time } t \text {, the rate of unemployment } \\
& \text { consistent with full employment at which the demand for labor equals the } \\
& \text { supply of labor. }
\end{aligned}
$$


Figure 1 shows what the Phillips curve relationship looked like for the United States before 1970. As we can see from Figure 1, the relationship worked well before 1970 and seems to suggest that there was a trade-off between unemployment and inflation: If policymakers wanted to have lower unemployment, they could "buy" it by accepting a higher rate of inflation. Combining this view with confidence in the ability of large-scale macroeconometric models to evaluate the effects of policy naturally led many economists in the 1960s to advocate activist policy measures to keep the economy at a target unemployment level.

However, there are three powerful arguments against monetary activism: (1) there are long and variable lags in the effects of monetary policy on the economy; (2) there is no long-run tradeoff between output (unemployment) and inflation; and (3) the time-inconsistency problem. These three arguments have so strongly undercut the case for monetary policy activism that support for it is now held by only a minority of economists. We look at each of these arguments in turn.

Long and Variable Lags. The first salvos that had a major impact against activism came from the monetarists led by Milton Friedman. Monetarists pointed out some serious flaws in Keynesian macroeconometric models. They also noted that the effects of macro policy were highly uncertain. Indeed, Milton Friedman staked out his famous position that activist policy would be counterproductive because policy, and particularly monetary policy, affects the economy only with "long and variable lags."

Although long lags, in and of themselves, do not rule out successful activism, there is a political economy argument why they make activist policy counterproductive. The public and particularly politicians often have a very myopic view of policy: that is, they only focus on the short-run and cannot understand that policy lags may be very long and indeed may be longer than the time it takes for the problem to correct itself. Therefore, politicians have a tendency to want immediate results and often fall into the trap of overmanipulating policy levers. In the case of monetary policy, this may lead policymakers to try to solve a problem such as too high unemployment using expansionary monetary policy, but by the time the expansionary policy is effective because of long lags, self-correcting mechanisms may have already returned the 
economy to full employment. The result is that activist monetary policy may lead to an overheated economy, which in turn leads either to inflation or to an attempt by policymakers to reign in the economy by reversing course, which can generate further economic instability. Monetarists therefore saw activist policy as having only a negative impact on the economy and instead advocated nonactivist policy such as a rule in which the money supply grows at a constant rate.

The view that the effects of monetary policy are variable and that this variability makes activist policy less attractive has been accepted not only by monetarists, but also by the large majority of the economics profession, who do not necessarily accept the monetarist position that macroeconomic policy should focus on the money supply and a monetary policy rule involving the growth rate of the money supply. Economists are no longer confident that macroeconometric models can accurately predict the impact of changes in both monetary and fiscal policy on the aggregate economy and, therefore, accept the view that the design of successful activist monetary policy is very difficult.

There are two primary reasons why the majority of the economics profession has come to doubt the usefulness of macroeconometric models to evaluate the impact of policy. One reason is that the performance of large macroeconometric models in both forecasting the economy and predicting the effect of policy has not been as good as the model builders once hoped. The second and more important reason is the so-called "Lucas critique" developed in Lucas's famous paper, "Econometric Policy Evaluation: A Critique," which already became very influential by the time I left graduate school in 1973, but was not published until $1976 .^{1}$ Lucas's challenge to policy evaluation using econometric models was based on a simple principle of rational expectations theory:

The way in which expectations are formed (the relationship of expectations to past information) changes when the behavior of forecasted variables changes.

So when policy changes, the relationship between expectations and past information will change,

${ }^{1}$ Lucas (1976). 
and because expectations affect economic behavior, the relationships in the econometric model will change. The econometric model which has been estimated with past data will then no longer be the correct model for evaluating the response to this policy change and may consequently prove highly misleading.

Along with the earlier monetarist criticisms of Keynesian macroeconometric models, the theoretical argument in the Lucas critique, when combined with a mixed performance of macroeconometric models in their ability to forecast and predict the effects of policy, dealt a body blow to the earlier optimism of the profession and the public that macroeconometric models could be used to design effective, activist stabilization policy.

No Long-Run Tradeoff Between Unemployment and Inflation. The second blow to policy activism was delivered by Milton Friedman in his famous presidential address to the American Economic Association in 1967. ${ }^{2}$ There Milton Friedman pointed out that the second principle supporting activist policy, the Phillips curve trade-off between unemployment and inflation, was incorrect. He pointed out a severe flaw in the Phillips curve analysis: It left out an important factor that affects wages and price inflation -- expectations of inflation.

Friedman noted that firms and workers are concerned with real variables, such as real wages, and are thus concerned with wages and costs of production that are adjusted for any expected increase in the price level. Workers and firms, therefore, take inflation into account when setting wages and prices, with the result that inflation will respond not only to tightness in the labor markets but also to expected inflation as well. This reasoning leads to an expectations-augmented Phillips curve in which the constant term in equation (1) is replaced by expected inflation, $\pi_{i}^{e}$, expressed as:

$$
\pi_{\mathrm{t}}=\pi_{\mathrm{t}}^{\mathrm{e}}-\alpha\left(\mathrm{U}_{\mathrm{t}}-\mathrm{U}_{\mathrm{t}}^{\mathrm{n}}\right)
$$

The expectations-augmented Phillips curve implies that as expected inflation rises, the Phillips curve will shift upward. Friedman's modification of the Phillips curve analysis was

${ }^{2}$ Friedman (1968). 
remarkably clairvoyant: As inflation increased in the late 1960s, the Phillips curve did indeed begin to shift upward, as we can see from Figure 2. An important feature of Figure 2 is that a long-run trade-off between unemployment and inflation no longer exists: As the points in the scatter diagram indicate, a high rate of inflation is no longer associated with a low rate of unemployment, or vice versa. This is exactly what the expectations-augmented Phillips curve predicts: A rate of unemployment below the natural rate of unemployment cannot be "bought" permanently by accepting a higher rate of inflation.

This prediction can be derived straightforwardly from the expectations-augmented Phillips curve as follows. When inflation is kept at a higher level for a substantial period of time, expected inflation would adjust upwards to a long-run value that would equal actual inflation. Substituting $\pi_{t}$ for $\pi_{t}^{e}$ in the expectations-augmented Phillips curve in equation (2) then yields:

$$
0=-\alpha\left(\mathrm{U}_{\mathrm{t}}-\mathrm{U}_{\mathrm{t}}^{\mathrm{n}}\right)
$$

which implies that $U_{t}=U_{t}^{n}$. This implies that in the long run, for any level of inflation, the unemployment rate will settle to its natural rate level: Hence the long-run Phillips curve is vertical, and there is no long-run trade-off between unemployment and inflation.

Indeed, if anything, the scatter plot in Figure 2 seems to suggest a slight tendency for unemployment and inflation to be positively correlated over the long run. In his Nobel prize address, Milton Friedman provided a rationale for why higher inflation might actually lead to higher, rather than lower, unemployment in the long run. ${ }^{3}$ His position that the long-run Phillips curve may even be positively sloped therefore provides additional ammunition against the pursuit of output goals and supports the desirability of a price stability goal.

The Time-Inconsistency Problem. The third intellectual development that argues against activist policy was developed in papers by Kydland and Prescott (1977), Calvo (1978) and Barro

\footnotetext{
${ }^{3}$ See Friedman (1977). Recent research such as Groshen and Schweitzer (1996) also suggests that the long-run Phillips curve may have a slight positive slope, particularly at inflation rates above $10 \%$.
} 
and Gordon (1983) and is commonly referred to as the time-inconsistency problem of monetary policy. The time-inconsistency problem stems from the view that economic behavior is influenced by expectations of future policy. A common way for making policy decisions is to assume that, at the time that policy is made, expectations are given. In the case of monetary policy, this means that with expectations fixed, policymakers know that they can boost economic output (or lower unemployment) by pursuing monetary policy that is more expansionary than expected. Thus, as a result, policymakers who have a high output objective will try to produce monetary policy that is more expansionary than expected. However, because their decisions about wages and prices reflect expectations about policy, workers and firms will not be fooled by the policymakers' expansionary monetary policy and so will raise not only their expectations of inflation but also wages and prices. The outcome is that policymakers are actually unable to fool workers and firms, so that, on average, output will not be higher under such a strategy, but unfortunately inflation will be. The time-inconsistency problem shows that a central bank may end up with a sub-optimal result of a bias to high inflation with no gains on the output front, even though the central bank believes that it is operating in an optimal manner.

Although the analysis of the time-inconsistency problem sounds somewhat complicated, it is actually a straightforward problem that we encounter in our every day life. Anyone who has children has had to deal with this problem continually. It is always easy to give in to children in order to keep them from acting up. However, the more the parent gives in, the more demanding a child becomes. The reason, of course, is that a child's expectations about the parent's policy changes depending on the parent's willingness to stand up to the child. Thus, giving in, although seemingly optimal based on the assumption that a child's expectations remain unchanged, leads to suboptimal policy because the child's expectations are affected by what the parent does. Similar reasoning applies to the conduct of foreign policy or any type of negotiation: it is very important not to give in to an opponent even if it makes sense at the time, because otherwise the opponent is more likely to take advantage of you in the future.

McCallum (1995) points out that the time-inconsistency problem by itself does not imply that a central bank will pursue expansionary monetary policy which leads to inflation. Simply by recognizing the problem that forward-looking expectations in the wage- and price-setting process creates for a strategy of pursuing unexpectedly expansionary monetary policy, central 
banks can decide not to play that game. Although McCallum's analysis is correct as far as it goes, it suggests that the time-inconsistency problem is just shifted back one step: even if the central bank recognizes the problem, there still will be pressures on the central bank to pursue overly expansionary monetary policy, with the result that expectations of overly expansionary monetary policy are still likely.

\section{The Gains from Price Stability}

The analysis above indicates that attempts to use monetary policy to pursue real output objectives are likely to be counterproductive. But it still leaves open the question of why price stability is the appropriate long-term goal for monetary policy. The answer is that price stability promotes an economic system that functions more efficiently.

If price stability does not persist, that is, inflation occurs, there are several economic costs to the society. While these costs tend to be much larger in economies with high rates of inflation (usually defined to be inflation in excess of $30 \%$ a year), recent work shows that substantial costs of inflation arise even at low rates of inflation as well.

The cost that first received the attention of economists is the so-called "shoe leather" cost of inflation, namely, the cost of economizing on the use of non-interest bearing money. ${ }^{4}$ The history of pre-war central Europe makes us all too familiar with the difficulties of requiring vast and ever rising quantities of cash to conduct daily transactions. Unfortunately, hyperinflations have occurred in emerging market countries within the last decade as well. Given conventional estimates of the interest elasticity of money and the real interest rate when inflation is zero, this cost is quite low for inflation rates less than $10 \%$, remaining below $0.10 \%$ of GDP. Only when inflation rises to above $100 \%$ do these costs become appreciable, climbing above $1 \%$ of GDP.

Another cost of inflation related to the additional need for transactions is the overinvestment in the financial sector that inflation produces. At the margin, opportunities to make profits by acting as a middleman on normal transactions, rather than investing in productive activities, increase with instability in prices. A number of estimates put the rise in

${ }^{4}$ See Bailey (1956). 
the financial sector's share of GDP on the order of 1 percentage point for every 10 percentage points of inflation up to an inflation rate of $100 \%$ (English (1996)). The transfer of resources out of productive uses elsewhere in the economy can be as large as a few percentage points of GDP, and can even be seen at relatively low or moderate rates of inflation.

The difficulties caused by inflation can extend to decisions about future expenditures as well. Higher inflation increases uncertainty both about relative prices and the future price level which makes it harder to make the appropriate production decisions. For example, in labor markets, Groshen and Schweitzer (1996) calculate that the loss of output due to inflation of 10 percent (compared to a level of 2 percent) is 2 percent of GDP. More broadly, the uncertainty about relative prices induced by inflation can distort not only the attractiveness of real versus nominal assets for investment, but also short-term versus long-term contracting, risk premia demanded on savings, and the frequency with which prices are changed (as in menu-cost stories). ${ }^{5}$

The most obvious costs of inflation at low to moderate levels seem to come from the interaction of the tax system with inflation. Because tax systems are rarely indexed for inflation, a rise in inflation substantially raises the cost of capital, which lowers investment below its optimal level. In addition, higher taxation which results from inflation causes misallocation of capital to different sectors that both distorts the labor supply and leads to inappropriate corporate financing decisions. Fischer (1994) calculates that the social costs from the tax-related distortions of inflation amount to 2 to 3 percent of GDP at an inflation rate of 10 percent. In a recent paper, Feldstein (1997) views this cost to be even higher: he calculates the cost of an inflation rate of $2 \%$ rather than zero to be $1 \%$ of GDP per year.

These costs of inflation outlined here decrease the level of resources productively employed in an economy, and thereby the base from which the economy can grow. There is mounting evidence from econometric studies that at high levels, inflation also decreases the rate of growth of economies as well. While long time-series studies of individual countries and cross-national comparisons of growth rates are not in total agreement, there is a consensus that on average a one percent rise in inflation can cost an economy 0.1 to 0.5 percentage points in

\footnotetext{
${ }^{5}$ Briault (1995) gives a good summary of these effects.
} 
its rate of growth (Fischer (1993)). This result varies greatly with the level of inflation, with the effects usually thought to be much higher at higher levels. ${ }^{6}$ However, a recent study has presented evidence that inflation variability associated with higher inflation has a significant negative effect on growth even at low levels of inflation, in addition to and distinct from the direct effect of inflation itself.

Bottom Line. In view of the long and variable lags in the effects of monetary policy on the economy, the weakened confidence in the ability of macro models to evaluate the effects of active policy, the recognition that no long-run tradeoff exists between unemployment and inflation, and the development of the theoretical literature on the time-inconsistency problem, both the economics profession and the public now doubt the efficacy of activist policies to eliminate unemployment. This case against monetary-policy activism, along with the recognition of the benefits of price stability in producing less uncertainty in the economy and a healthier economic environment and thereby leads to greater real activity and economic growth, have led to an emerging consensus that price stability should be the overriding long-run goal for monetary policy.

\section{III. Strategies for Controlling Inflation}

With the growing consensus that price stability should be the overriding long-run goal of monetary policy, many countries have taken active steps to reduce and control inflation. What strategies have they used to do this?

There are four basic strategies that central banks have used to control and reduce inflation: 1) exchange rate pegging, 2) monetary targeting, 3) inflation targeting, and 4) inflation

6 Sarel (1996), for example, presents a strong argument that the growth costs of inflation are nonlinear, and rise significantly when inflation exceeds 8 percent annually.

${ }^{7}$ Judson and Orphanides (1996). Hess and Morris (1996) also disentangles the relationship between inflation variability and inflation level for low inflation countries. 
reduction without an explicit nominal anchor, which, for want of a better name, might best be referred to as "just do it." Here, we will look at each of these strategies in turn and discuss the advantages and disadvantages of each in order to provide a critical evaluation.

\section{Exchange Rate Pegging}

One commonly used method to reduce inflation and keep it low is for a country to peg the value of its currency to that of a large, low-inflation country. In some cases, this strategy involves pegging the exchange rate at a fixed value to that of the other country so that its inflation rate will eventually gravitate to that of the other country, while in other cases it involves a crawling peg or target in which its currency is allowed to depreciate at a steady rate so that its inflation rate can be higher than that of the other country.

Advantages. A key advantage of an exchange rate peg is that it provides a nominal anchor which can prevent the time-inconsistency problem. As discussed above, the time-inconsistency problem arises because a policymaker (or the politicians who have influence over the policymaker) have an incentive to pursue expansionary policy in order to raise economic output and create jobs in the short run. If policy can be bound by a rule that prevents policymakers from playing this game, then the time-inconsistency problem can be avoided. Indeed, this is what an exchange rate peg can do if the commitment to it is strong enough. With a strong commitment, the exchange rate peg implies an automatic monetary policy rule that forces a tightening of monetary policy when there is a tendency for the domestic currency to depreciate or a loosening of policy when there is a tendency for the domestic currency to appreciate. The central bank no longer has the discretion that can result in the pursuit of expansionary policy to obtain output gains which leads to time-inconsistency.

Another important advantage of an exchange rate peg is its simplicity and clarity, which makes it easily understood by the public: a "sound currency" is an easy-to-understand rallying cry for monetary policy. For example, the Banque de France has frequently appealed to the "franc fort" in order to justify tight monetary policy. In addition, an exchange rate peg can 
anchor price inflation for internationally traded goods and, if the exchange rate peg is credible, help the pegging country inherit the credibility of the low-inflation country's monetary policy. As a result, an exchange rate peg can help lower inflation expectations quickly to those of the targeted country. ${ }^{8}$ This should help bring inflation in line with that of the low-inflation country reasonably quickly.

An exchange rate peg to control inflation has been used quite successfully in industrialized countries. For example, in Figure 3, we see that, by tying the value of the franc closely to the German mark, France has kept inflation low. In 1987, when France first started tying the value of the franc closely to the German mark, its inflation rate was $3 \%$, two percentage points above the German inflation rate (Figure 4). By 1992, its inflation rate had fallen to $2 \%$ and was below that in Germany. By 1996, the French and German inflation rates were nearly identical, slightly below the $2 \%$ level. Similarly, by pegging to the German mark in 1990, the United Kingdom was able to lower its inflation rate from $10 \%$ to $3 \%$ when it was forced to abandon the Exchange Rate Mechanism (ERM) peg in 1992 (Figure 5).

Exchange rate pegging can be an especially effective means of reducing inflation quickly if there is a very strong commitment to the exchange rate peg. A particularly strong form of commitment mechanism to a pegged exchange rate is a currency board. A currency board requires that the note-issuing authority, whether the central bank or the government, announces a fixed exchange rate against a particular foreign currency and then stands ready to exchange domestic currency for foreign currency at that rate whenever the public requests it. In order to credibly meet these requests, a currency board typically has more than $100 \%$ foreign reserves backing the domestic currency and allows the monetary authorities absolutely no discretion. In contrast, the typical fixed or pegged exchange rate regime does allow the monetary authorities some discretion in their conduct of monetary policy because they can still adjust interest rates or conduct open market operations which affect domestic credit. The currency board thus involves a stronger commitment by the central bank to the fixed exchange rate and may therefore be even more effective in bringing down inflation quickly.

An important recent example in which a currency board was implemented to reduce

${ }^{8}$ See Bruno (1991) 
inflation is Argentina. Because of continuing bouts of hyperinflation and previous past failures of stabilization programs, the Argentine government felt that the only way it could break the back of inflation was to adopt a currency board, which it did in 1990 by passing the Convertibility Law. This law required the central bank to exchange U.S. dollars for new pesos at a fixed exchange rate of 1 to 1 . The early years of Argentina's currency board looked stunningly successful. Inflation which had been running at over a 1,000\% annual rate in 1989 and 1990 fell to well under $5 \%$ by the end of 1994 and economic growth was rapid, averaging almost an 8\% annual rate from 1991 to 1994 (see Figures 6).

Disadvantages. However, there are some quite serious difficulties that arise from an exchange rate peg. One of the key disadvantages stems from the loss of an independent monetary policy for the pegging country. As long as a country has open capital markets, interest rates in a country pegging its exchange rate are closely linked to those of the anchor country it is tied to, and its money creation is constrained by money growth in the anchor country. A country that has pegged its currency to that of the anchor country therefore loses the ability to use monetary policy to respond to domestic shocks that are independent of those hitting the anchor country. For example, if there is a decline in domestic demand specific to the pegging country, say because of a decline in the domestic government's spending or a decline in the demand for exports specific to that country, monetary policy cannot respond by lowering interest rates because these rates are tied to those of the anchor country. The result is that both output and even inflation may fall below desirable levels, with the monetary authorities powerless to stop these movements.

Furthermore, with a pegged exchange rate, shocks specific to the anchor country will be more easily transmitted to the targeting country. A clear-cut example of this occurred with German reunification in 1990. Concerns about inflationary pressures arising from reunification and the massive fiscal expansion required to rebuild East Germany led to rises in German longterm interest rates until February 1991 and to rises in short-term rates until December 1991. Although German reunification was clearly a shock specific to Germany, the anchor country in 
the Exchange Rate Mechanism (ERM), it was transmitted directly to the other countries in the ERM whose currencies were pegged to the mark because their interest rates now rose in tandem with those in Germany. The result was a significant slowing of economic growth in countries such as France, as illustrated in Figure 3.

Another important disadvantage of a pegged exchange rate regime is that, as emphasized in Obstfeld and Rogoff (1995), it leaves countries open to speculative attacks on their currencies. Indeed, the aftermath of German reunification was a European exchange rate crisis in September 1992. As we have seen, the tight monetary policy in Germany resulting from German reunification meant that the countries in the ERM were subjected to a negative demand shock that led to a decline in economic growth and a rise in unemployment. It was certainly feasible for the governments of these countries to keep their exchange rates fixed relative to the mark in these circumstances, but speculators began to question whether these countries' commitment to the exchange rate peg would weaken because the countries would not tolerate the rise in unemployment and thus would not keep interest rates sufficiently high to fend off speculative attacks on their currencies.

At this stage, speculators were in effect presented with a one-way bet: the exchange rates for currencies such as the French franc, the Spanish peseta, the Swedish krona, the Italian lira and the British pound could only go in one direction, depreciate against the mark. Selling these currencies thus presented speculators with an attractive profit opportunity with potentially high expected returns and yet little risk. The result was that in September 1992, a speculative attack on the French franc, the Spanish peseta, the Swedish krona, the Italian lira and the British pound began in earnest. Only in France was the commitment to the fixed exchange rate strong enough, with France remaining in the ERM. The governments in Britain, Spain, Italy and Sweden were unwilling to defend their currencies at all costs and so devalued their currencies.

The attempted defense of these currencies did not come cheaply. By the time the crisis was over, the British, French, Italian, Spanish and Swedish central banks had intervened to the tune of an estimated $\$ 100$ billion, and the Bundesbank alone had laid out an estimated $\$ 50$ billion for foreign exchange intervention. It is further estimated that these central banks lost $\$ 4$ to $\$ 6$ billion as a result of their exchange-rate intervention in the crisis, an amount that was in effect paid by taxpayers in these countries. 
The different response of France and the United Kingdom after the September 1992 exchange rate crisis (shown in Figures 3 and 5) also illustrates the potential cost of using an exchange rate peg to control inflation. France, which continued to peg to the mark and thereby was unable to use monetary policy to respond to domestic conditions, found that economic growth remained slow after 1992 and unemployment increased. The United Kingdom, on the other hand, which dropped out of the ERM exchange rate peg, had much better economic performance: economic growth was higher, the unemployment rate fell, and yet inflation performance was not much worse than France's.

The aftermath of German reunification and the September 1992 exchange rate crisis dramatically illustrate two points: 1) a fixed or pegged exchange rate does not guarantee that the commitment to the exchange-rate based, monetary policy rule is strong, and 2) the cost to economic growth from an exchange rate peg that results in a loss of independent monetary can be high.

The September 1992 episode and its aftermath suggest that using exchange rate pegs to control inflation may be problematic in industrialized countries. However, exchange rate pegs may be an even more dangerous strategy for controlling inflation in emerging market countries.

As pointed out in Mishkin (1996), in emerging market countries, a foreign exchange crisis can precipitate a full scale financial crisis in which financial markets are no longer able to move funds to those with productive investment opportunities, thereby causing a severe economic contraction. Because of uncertainty about the future value of the domestic currency, many nonfinancial firms, banks and governments in emerging market countries find it much easier to issue debt if the debt is denominated in foreign currencies. This was a prominent feature of the institutional structure in the Chilean financial markets before the financial crisis in 1982 and in Mexico in 1994. This institutional feature implies that, when there is an unanticipated depreciation or devaluation of the domestic currency, the debt burden of domestic firms increases. On the other hand, since assets are typically denominated in domestic currency, there is no simultaneous increase in the value of firms' assets. The result is a that a depreciation leads to a substantial deterioration in firms' balance sheets and a decline in net worth, which, in turn, means that their effective collateral has shrunk, thereby providing less protection to lenders. Furthermore, the decline in net worth increases moral hazard incentives for firms to 
take on greater risk because they have less to lose if the loans go sour. Because lenders are now subject to much higher risks of losses, there is now a decline in lending and hence a decline in investment and economic activity.

Mexico's recent experience illustrates how dangerous using an exchange rate peg to control inflation can be in emerging market countries. After experiencing very high inflation rates, Mexico decided to peg the peso to the dollar in December 1987 and moved to a crawling peg in January 1989. Up until December 1994, this strategy appeared to be highly successful. Inflation fell from over $100 \%$ in 1987 to below $10 \%$ in 1993 and 1994, while economic growth averaged over $3.5 \%$ from 1988 to 1994 (see Figure 7).

However, with the Colosio assassination and other political developments such as the uprising in Chiapas, the Mexican peso began to come under attack. Given the commitment to a pegged exchange rate, the Banco de Mexico intervened in the foreign exchange market to purchase pesos, with the result that there was a substantial loss of international reserves, but because of the weakness of the banking sector, speculators began to suspect that the Mexican authorities were unwilling to raise interest rates sufficiently to defend the currency. By December, the speculative attack had begun in earnest, and even though the Mexican central bank raised interest rates sharply, the hemorrhaging of international reserves forced the Mexican authorities to devalue the peso on December 20, 1994.

By March 1995, the peso had halved in value. The depreciation of the peso starting in December 1994 led to an especially sharp negative shock to the net worth of private firms, which decreased the willingness of lenders to lend to these firms. In addition, the depreciation of the peso led to a deterioration in the balance sheets of Mexican banks; the banks had many short-term liabilities denominated in foreign currency which then increased sharply in value, while the problems of firms and households meant that they were unable to pay off their debts, resulting in loan losses on the assets side of the banks' balance sheets. The result of the deterioration in the balance sheets of both nonbanking and banking firms was a financial and banking crisis that led to a collapse of lending and economic activity (see Figure 7). ${ }^{9}$

${ }^{9}$ See Mishkin (1996) for a more extensive treatment of the mechanisms which produced a financial crises and economic collapse in Mexico in the 1994-95 period. 
An additional danger from using an exchange-rate peg to control inflation in emerging market countries is that a successful speculative attack can actually lead to higher inflation. Because many emerging market countries have previously experienced both high and variable inflation, their central banks are unlikely to have deep-rooted credibility as inflation fighters. Thus, a sharp depreciation of the currency after a speculative attack that leads to immediate upward pressure on prices is likely to lead to a dramatic rise in both actual and expected inflation. Indeed, as we see in Figure 7, Mexican inflation surged to 50\% in 1995 after the foreign exchange crisis in 1994.

A rise in expected inflation after a successful speculative attack against the currency of an emerging market country can also exacerbate the financial crisis because it leads to a sharp rise in interest rates. The interaction of the short duration of debt contracts and the interest rate rise leads to huge increases in interest payments by firms, thereby weakening firms' cash flow position and further weakening their balance sheets. Then, as we have seen, both lending and economic activity are likely to undergo a sharp decline.

A further disadvantage of an exchange rate peg is that it can make policymakers less accountable for pursuing anti-inflationary policies because it eliminates an important signal both to the public and policymakers that too expansionary policies may be in place. The daily fluctuations in the exchange rate provide information on the stance of monetary policy, and this cannot happen with an exchange rate peg. A depreciation of the exchange rate may provide an early warning signal to the public and policymakers that policies may have to be adjusted in order to limit the potential for a financial crisis. Thus, like the long-term bond market, the foreign exchange market can constrain policy from being too expansionary. Just as the fear of a visible inflation scare in the bond market that causes bond prices to decline sharply constrains politicians from encouraging overly expansionary monetary policy, fear of immediate exchange rate depreciations can constrain politicians in countries without long-term bond markets from supporting overly expansionary policies.

Although the stronger commitment to a fixed exchange rate may mean that a currency board is better able to stave off a speculative attack against the domestic currency than an exchange-rate peg, it is not without its problems. In the aftermath of the Mexican peso crisis, concern about the health of the Argentine economy resulted in the public pulling their money 
out of the banks (deposits fell by 18\%) and exchanging their pesos for dollars, thus causing a contraction of the Argentine money supply. The result was a sharp contraction in Argentine economic activity (Figure 6) with real GDP dropping sharply over 5\% in 1995 and the unemployment rate jumping to above $15 \%$ (see Figure 6). Only in 1996, with financial assistance from international agencies such as the IMF, the World Bank and the Inter-American Development Bank, which lent Argentina over $\$ 5$ billion to help shore up its banking system, did the economy begin to recover. Because the central bank of Argentina had no control over monetary policy under the currency board system, it was relatively helpless to counteract the contractionary monetary policy stemming from the public's behavior. Furthermore, because the currency board does not allow the central bank to create money and lend to the banks, it limits the capability of the central bank to act as a lender of last resort, and other means must be used to cope with potential banking crises.

Although a currency board is highly problematic, it may be the only way to break a country's inflationary psychology and alter the political process so that the political process no longer leads to continuing bouts of high inflation. This indeed was the rationale for putting a currency board into place in Argentina, where past experience had suggested that stabilization programs with weaker commitment mechanisms would not work. Thus, implementing a currency board may be a necessary step to control inflation in countries that require a very strong disciplinary device. However, as discussed here, this form of discipline is not without its dangers.

It is also important to recognize that emerging market countries are far more vulnerable to disastrous consequences from a successful speculative attack on their currencies than industrialized countries. Industrialized countries have a history of low inflation and have much less debt denominated in foreign currencies. Thus, a depreciation of the currency does not lead to a deterioration of firms' balance sheets or a sharp rise in expected inflation. Indeed, as the performance of the United Kingdom after the September 1992 foreign exchange crisis illustrates, an industrialized country that has its currency depreciate after a successful speculative attack may do quite well. The United Kingdom's economic performance after September 1992 was extremely good: inflation remained low and real growth was high. The different response to speculative attacks in industrialized versus emerging market countries suggests that, although 
using an exchange rate peg to control inflation in industrialized countries is not without severe problems, it may be even more dangerous to use such a peg to control inflation in emerging market countries.

\section{Monetary Targeting}

We have seen that using an exchange-rate peg to control inflation is not without its problems. However, in many countries, an exchange-rate peg is not even an option because the country (or block of countries) is too large or has no natural country to which to anchor its currency. Another strategy for controlling inflation is monetary aggregate targeting. For example, the collapse of a fixed-exchange-rate Bretton Woods regime encouraged monetary targeting by many countries, especially Germany and Switzerland starting in the mid-1970s.

One way of pursuing monetary targeting is to follow Milton Friedman's suggestion for a constant-money-growth-rate rule in which the chosen monetary aggregate, say M2, is targeted to grow at a constant rate. In practice, even among the most avid monetary targeters, a quite different approach has been used. As pointed out in Bernanke and Mishkin (1992), no monetary-targeting central bank has ever adhered to strict, ironclad rules for monetary growth. Instead, monetary targeting is quite flexible: all monetary targeters deviate significantly from their monetary growth targets in order to be responsive to short-term objectives such as real output growth and exchange rate considerations, and are very explicit about their willingness to be flexible and pragmatic. ${ }^{10}$

Advantages. A major advantage of monetary targeting over exchange rate pegging is that it enables a central bank to adjust its monetary policy to cope with domestic considerations. It enables the central bank to choose goals for inflation that may differ from those of other countries and allows some response to output fluctuations.

Monetary targeting also has several advantages in common with exchange rate pegging.

\footnotetext{
${ }^{10}$ This is particularly true of Germany, the quintessential monetary targeter. Besides Bernanke and Mishkin (1992), see Clarida and Gertler (1997) and Mishkin and Posen (1997).
} 
First is that a target for the growth rate of a monetary aggregate provides a nominal anchor that is fairly easily understood by the public. (However, the target may not be quite as easily comprehended as an exchange rate target.) Also like an exchange rate peg, information on whether the central bank is achieving its target is known almost immediately -- announced figures for monetary aggregates are typically reported periodically with very short time-lags, within a couple of weeks. Thus, monetary targets can send almost immediate signals to both the public and markets about the stance of monetary policy and the intentions of the policymakers to keep inflation in check. These signals then can help fix inflation expectations and produce less inflation. Second, monetary targets also have the advantage of being able to promote almost immediate accountability for monetary policy to keep inflation low and so constrain the monetary policymaker from falling into the time-inconsistency trap.

The prime example of a monetary targeting regime is that of Germany which has engaged in monetary targeting for over twenty years. A key feature of the German monetary-targeting framework is the strong commitment to transparency and communication of the strategy of monetary policy to the public. As is emphasized in Bernanke and Mishkin (1992) and Mishkin and Posen (1997), the calculation of target ranges is a very public exercise. First and foremost, a numerical inflation goal is prominently featured in the setting of the target ranges. Then with estimates of potential output growth and velocity trends, a quantity equation framework is used to generate the desired monetary growth rate. The Bundesbank also spends tremendous effort, both in its publications (the Monthly Report and Annual Report) and in frequent speeches by members of its governing council, to communicate to the public what the central bank is trying to achieve. Indeed, given that the Bundesbank frequently has missed its monetary targets with both significant overshoots and undershoots, its monetary-targeting framework might be best viewed as a mechanism for transparently communicating how monetary policy is being conducted to achieve the Bundesbank's inflation goals and as a means for increasing the accountability of the central bank.

As Figure 3 suggests, Germany's monetary-targeting regime has been quite successful in producing low inflation. Indeed, an important success story occurred in the aftermath of German reunification in 1990. (This episode is discussed extensively in Mishkin and Posen [1997].) Despite a temporary surge in inflation stemming from the terms of reunification, the 
high wage demands and the fiscal expansion, the Bundesbank was able to keep these one-off effects from becoming embedded in the inflation process, and by 1995, inflation fell below the Bundesbank's inflation goal of $2 \%$.

Disadvantages. All of the above advantages of monetary aggregate targeting depend on two big ifs. The biggest if is that there must be a strong and reliable relationship between the goal variable (inflation and nominal income) and the targeted aggregate. If there is velocity instability, so that the relationship between the monetary aggregate and the goal variable (such as inflation) is weak, then monetary aggregate targeting will not work. The weak relationship implies that hitting the target will not produce the desired outcome on the goal variable and thus the monetary aggregate will no longer provide an adequate signal about the stance of monetary policy. Thus, monetary targeting will not help fix inflation expectations and be a good guide for assessing the accountability of the central bank. The breakdown of the relationship between monetary aggregates and goal variables such as inflation and nominal income certainly seems to have occurred in the United States (Stock and Watson [1989], Friedman and Kuttner [1993, 1996], and Estrella and Mishkin [1996]) and may also be a problem even for countries that have continued to pursue monetary targeting.

The second if is that the targeted monetary aggregate must be well controlled by the central bank. If not, the monetary aggregate may not provide as clear signals about the intentions of the policymakers and thereby make it harder to hold them accountable. Although narrow monetary aggregates are easily controlled by the central bank, it is far from clear that this is the case for broader monetary aggregates like M2 or M3 (see B. Friedman [1995]).

These two problems with monetary targeting suggest one reason why even the most avid monetary targeters do not rigidly hold to their target ranges, but rather allow undershoots and overshoots for extended periods of time. Moreover, an unreliable relationship between monetary aggregates and goal variables calls into question the ability of monetary targeting to serve as a communications device that both increases the transparency of monetary policy and makes the central bank accountable to the public. 


\section{Inflation Targeting}

Because of the breakdown in the relationship between monetary aggregates and goal variables such as inflation, many countries have abandoned monetary targeting -- or as attributed to John Crow, the former governor of the Bank of Canada, "We didn't abandon monetary aggregates, they abandoned us." Another choice for a monetary-policy strategy that has become increasingly popular in recent years is inflation targeting, which involves the public announcement of medium-term numerical targets for inflation with a commitment by the monetary authorities to achieve these targets. ${ }^{11}$ Additional key features of inflation-targeting regimes include increased communication with the public and the markets about the plans and objectives of monetary policymakers and increased accountability of the central bank for obtaining its inflation objectives.

Advantages. The primary advantage of inflation targeting is its transparency to the public. Like monetary aggregates and exchange rate targets, it is readily understood by the public, but, even more directly than the others, it makes clear the commitment to price stability. Inflation targeting keeps the goal of price stability in the public's eye, thus making the central bank more accountable for keeping inflation low which helps counter the time-inconsistency problem.

In contrast to the exchange rate target, but like the monetary aggregate target, inflation targets enable monetary policy to focus on domestic considerations and to respond to shocks to the economy. Finally, inflation targets have the advantage that velocity shocks are largely irrelevant because the monetary policy strategy no longer requires a stable money-inflation relationship. Indeed, an inflation target allows the monetary authorities to use all available information, and not just one variable, to determine the best settings for monetary policy.

The increased accountability of the central bank under inflation targeting can also help reduce political pressures on the central bank to pursue inflationary monetary policy and thereby avoid the time-inconsistency problem. Moreover, inflation targeting helps focus the political

${ }^{11}$ Detailed analyses of experiences with inflation targeting can be found in Goodhart and Vinals (1994), Leiderman and Svensson (1995), Haldane (1995) and McCallum (1996), among others. 
debate on what a central bank can do -- that is control inflation -- rather than what it cannot do - raise economic growth permanently by pursuing expansionary policy. An interesting example of this occurred in Canada in 1996, discussed extensively in Mishkin and Posen (1997), when the president of the Canadian Economic Association criticized the Bank of Canada for pursuing monetary policy that was too contractionary. The existence of the inflation target helped channel a debate on whether the Bank of Canada was pursuing too contractionary a policy into a substantive discussion over what should be the appropriate target level for inflation, with both the Bank and its critics having to make explicit their assumptions and estimates of the costs and benefits of different levels of inflation. Indeed, as a result of the debate, the Bank of Canada won support through its response, its responsiveness, and its record, with the result that criticism of the Bank was not a major issue in the run-up to the 1997 elections as it had been before the 1993 elections.

The first three countries to adopt formal inflation targets were New Zealand, Canada and the United Kingdom. All three have found this monetary policy strategy to be very effective in keeping inflation under control, as can be seen in Figures 5, 8 and 9. After implementing inflation targeting in 1990, New Zealand continued a disinflation that had started in the mid 1980s, and since 1992 core inflation has remained within the inflation target range of 0 to $2 \%$ most of the time. ${ }^{12}$

Shortly after adopting inflation targets in February 1991, the Bank of Canada was faced with a hike in the value-added tax, a negative supply shock that in the past might have led to a ratcheting up in inflation. Instead, this supply shock led to only a one-time increase in the price level and was not passed through to a persistent rise in the inflation rate. Indeed, after the initial effect of the tax rise, inflation resumed its downward trend, causing the inflation targets to even be undershot. By 1992, inflation had fallen to below $2 \%$ and has remained close to this level ever since, which can arguably be viewed as achieving price stability.

After the September 1992 foreign exchange crisis, when the British were forced out of the ERM and therefore lost their exchange-rate nominal anchor, the British government resorted to an inflation-targeting regime to keep inflation in check. Inflation continued its downward

\footnotetext{
${ }^{12}$ Since December 1996, the inflation target range has been widened to 0-3\%.
} 
trend and, by November 1993, it had fallen to the midpoint of the target range of $2.5 \%$. The inflation-targeting regime in the United Kingdom was not without its problems, however, because it was conducted under severe political constraints: that is, under a system in which the government, not the central bank set the monetary policy instruments. As a result, accountability for achieving the inflation targets was unclear: whether it was the agency that made the public forecasts (the Bank of England) or the agency that set the monetary policy instruments (the Chancellor of the Exchequer). This lack of accountability led to much confusion as to the degree of commitment to the inflation targets, an issue that was finally resolved with the May 1997 announcement by the Labour government that it would grant operational independence to the Bank of England and make it fully accountable for achieving the inflation targets. Yet, even given this handicap, British inflation targeting, which had been accompanied by intensive efforts by the Bank of England to communicate clearly and actively with the public, has been associated with lower and more stable inflation rates, something that might not necessarily have been expected given past British experience.

Given the success of inflation targeting in controlling inflation in New Zealand, Canada and the United Kingdom, other countries such as Australia, Finland, Israel, Spain and Sweden have followed in their footsteps and adopted inflation targets.

Disadvantages. Although inflation targeting has been successful in controlling inflation in countries that have adopted it, it is not without criticisms. In contrast to exchange rates and monetary aggregates, inflation is not easily controlled by the monetary authorities. Furthermore, because of the long lags in the effects of monetary policy, inflation outcomes are revealed only after a substantial lag. Thus, an inflation target is unable to send immediate signals to both the public and markets about the stance of monetary policy. However, we have seen that the signals provided by monetary aggregates may not be very strong, while an exchange rate peg may obscure the ability of the foreign exchange market to signal that overly expansionary policies are in place. Thus, inflation targeting may nevertheless dominate these other strategies for the conduct of monetary policy. 
Some economists, such as Friedman and Kuttner (1996), have criticized inflation targeting because they believe that it imposes a rigid rule on monetary policymakers that does not allow them enough discretion to respond to unforeseen circumstances. This criticism is one that has featured prominently in the rules-versus-discretion debate. For example, policymakers in countries that adopted monetary targeting did not foresee the breakdown of the relationship between these aggregates and goal variables such as nominal spending or inflation. With rigid adherence to a monetary rule, the breakdown in their relationship could have been disastrous. However, the interpretation of inflation targeting as a rule is incorrect and stems from a confusion that has been created by the rules-versus-discretion debate. In my view, the traditional dichotomy between rules and discretion can be highly misleading. Useful policy strategies exist that are "rule-like" in that they involve forward-looking behavior which constrains policymakers from systematically engaging in policies with undesirable long-run consequences, thereby avoiding the time-inconsistency problem. These policies would best be described as "constrained discretion."

Indeed, inflation targeting can be described exactly in this way. As emphasized in Bernanke and Mishkin (1997) and Mishkin and Posen (1997), inflation targeting as actually practiced is very far from a rigid rule. First, inflation targeting does not provide simple and mechanical instructions as to how the central bank should conduct monetary policy. Rather, inflation targeting requires that the central bank use all available information to determine what are the appropriate policy actions to achieve the inflation target. Unlike simple policy rules, inflation targeting never requires the central bank to ignore information and focus solely on one key variable.

Second, inflation targeting as practiced contains a substantial degree of policy discretion. Inflation targets have been modified depending on economic circumstances. Furthermore, central banks under inflation-targeting regimes have left themselves considerable scope to respond to output growth and fluctuations through several devices. First, the price index on which the official inflation targets are based is often defined to exclude or moderate the effects of "supply shocks;" for example, the officially targeted price index may exclude some combination of food and energy prices, indirect tax changes, terms-of-trade shocks, and the direct effects of interest rate changes on the index (for example, through imputed rental costs). 
Second, as already noted, inflation targets are typically specified as a range. While the use of ranges generally reflects uncertainty about the link between policy levers and inflation outcomes but is also intended to allow the central bank some flexibility in the short run. Third, short-term inflation targets can and have been adjusted to accommodate supply shocks or other considerations, such as the value of the exchange rate. This accommodation is done either by modifications to the inflation target or by having an explicit escape clause in which the inflation target can be suspended or modified in the face of certain adverse economic developments.

However, despite its flexibility, inflation targeting is not an exercise in policy discretion subject to the time-inconsistency problem. Because an inflation target by its nature must be forward looking and because inflation targeting makes a central bank highly accountable by transparently making clear how it is to be evaluated, inflation targeting constrains discretion so that the time-inconsistency problem is ameliorated.

An important criticism of inflation targeting is that a sole focus on inflation may lead to larger output fluctuations. However, a counter to this argument is that inflation targeting provides not only a ceiling for the inflation rate, but also a floor. Inflation targeting thus can act to attenuate the effects of negative, as well as positive, shocks to aggregate demand. An interesting historical example is that of Sweden in the 1930s, which adopted a "norm of price stabilization" after leaving the gold standard in 1931. As a result, Sweden did not undergo the devastating deflation experienced by other countries during the Great Depression (Jonung, 1979). It is almost always true that the process of disinflation itself has costs in lost output and unemployment, and these costs may well increase the closer one comes to price stability. ${ }^{13}$

Nevertheless, disappointingly, there is little evidence that inflation targeting lowers sacrifice ratios even when central banks have adopted inflation targets and have credibly maintained price stability for a length of time. ${ }^{14}$ Indeed, as we have seen in inflation-targeting countries such as New Zealand and Canada (Figure 8 and 9), the decline in inflation that occurred even with inflation targets was accompanied by slow growth and a rise in

${ }^{13}$ This is an implication of the Akerlof, Dickens and Perry (1996) argument that lower inflation may lead to higher unemployment because of downward rigidities in nominal wages.

${ }^{14}$ Debelle and Fischer (1994) and Posen (1995). 
unemployment. Only after the disinflation had taken place did these economies begin to experience high growth rates.

The experience with costly disinflations suggests that a single-minded focus on inflation may be undesirable. For this reason, several economists have proposed that central banks should target the growth rate of nominal GDP rather than inflation (Taylor, 1985; Hall and Mankiw, 1994). Nominal GDP growth has the advantage that it does put some weight on output as well as prices. Under a nominal GDP target, a decline in projected real output growth would automatically imply an increase in the central banks inflation target, which would tend to be stabilizing. ${ }^{15}$ Cecchetti (1995) has presented simulations suggesting that policies directed to stabilizing nominal GDP growth may be more likely than inflation targeting to produce good economic outcomes, given the difficulty of predicting and controlling inflation.

Nominal GDP targeting is a strategy that is quite similar to inflation targeting and has many of the same advantages and so is a reasonable alternative. However, there are two reasons why inflation targets are preferable to nominal GDP targets. First, a nominal GDP target forces the central bank or the government to announce a number for potential GDP growth. Such an announcement is highly problematic because estimates of potential GDP growth are far from precise and change over time. Announcing a specific number for potential GDP growth may thus indicate a certainty that policymakers may not have and may also cause the public to mistakenly believe that this estimate is actually a fixed target for potential GDP growth. Announcing a potential GDP growth number is likely to be political dynamite because it opens policymakers to the criticism that they are willing to settle for growth rates that the public many consider to be too low. Indeed, a nominal GDP target may lead to an accusation that the central bank or the targeting regime is anti-growth, when the opposite is true because a low inflation rate is a means to promote a healthy economy that can experience high growth. In addition, if the estimate for potential GDP growth is too high and becomes embedded in the public mind as a target, it leads to the classic time-inconsistency problem demonstrated in the model of Barro and Gordon (1983) in which there is a positive inflation bias.

\footnotetext{
${ }^{15} \mathrm{Hall}$ and Mankiw (1994) point out that the equal weighting of real output growth and inflation implied by a nominal GDP targeting is not necessarily the optimal one; in general, the relative weight put on the two goal variables should reflect social preferences.
} 
A second reason why inflation targets are preferable to nominal GDP targets relates to the likelihood that the concept of inflation is much better understood by the public than the concept of nominal GDP, which is often easily confused with real GDP. If this is so, the objectives of communication and transparency would be better served by the use of an inflation target. Furthermore, because nominal and real GDP can easily be confused, a nominal GDP target may lead the public to believe that a central bank is targeting real GDP growth, something that is highly problematic as explained above.

It is important to recognize that, given the various escape clauses and provisions for short-run flexibility built into the inflation-targeting approach, there is little practical difference in the degree to which inflation targeting and nominal GDP targeting would allow for accommodation of short-run stabilization objectives. Thus, inflation targeting has almost all the benefits of nominal GDP targeting, but does not suffer from the disadvantages discussed.

\section{Just Do It: Preemptive Monetary Policy without an Explicit Nominal Anchor}

Several countries in recent years, most notably the United States, have been able to successfully reduce and control inflation without an explicit nominal anchor such as an exchange rate, a monetary aggregate target, or an inflation target. Although in these cases, there is no explicit strategy that is clearly articulated, there is a coherent strategy for the conduct of monetary policy nonetheless. This strategy involves forward-looking behavior in which preemptive monetary policy strikes against inflation are conducted periodically.

As emphasized earlier, monetary policy effects have long lags. In industrialized countries with a history of low inflation, the inflation process seems to have tremendous inertia: estimates from large macroeconometric models of the U.S. economy, for example, suggest that monetary policy takes as long as two years to affect output and three years to have a significant impact on inflation. For other countries whose economies respond more quickly to exchange rate changes or that have experienced highly variable inflation, and therefore have more flexible prices, the lags may be shorter. 
The presence of long lags means that monetary policy must not wait until inflation has already reared its ugly head before responding. By waiting until inflation has already appeared, the monetary authorities will be too late; inflation expectations will already be embedded in the wage- and price-setting process, creating an inflation momentum that will be hard to halt. Once the inflation process has gotten rolling, the process of stopping it will be slower and costlier.

In order to prevent inflation from getting started, monetary authorities must therefore behave in a forward-looking fashion and act preemptively: that is, depending on the lags from monetary policy to inflation, policymakers must act well before inflationary pressures appear in the economy. For example, if it takes roughly three years for monetary policy to have its full impact on inflation, then, even if inflation is quiescent currently and yet, with an unchanged stance of monetary policy, policymakers see inflation rising over the next three years, they must act today to tighten monetary policy to prevent the inflationary surge.

This preemptive monetary policy strategy is clearly also a feature of inflation-targeting regimes because monetary policy instruments must be adjusted to take account of the long lags in their effects in order to hit future inflation targets. However, the "just do it" strategy differs from inflation targeting in that it does not officially have a nominal anchor and is much less transparent in its monetary policy strategy.

Advantages. The main advantage of the "just do it" policy is that it has worked well in the past. As we can see in Figure 10, the Federal Reserve has been able to bring down inflation in the United States from double digit levels in 1980 to around the 3\% level by the end of 1991 and has kept it in a narrow range around this level since then. Indeed, the performance of the U.S. economy has been the envy of the industrialized world in the 1990s: inflation has remained low, real GDP growth has been high, while unemployment has been well below that of the majority of the other OECD countries. The "just do it" strategy has the advantage of central banks solving the time-inconsistency problem by engaging in forward-looking behavior, along the lines McCallum (1995) has suggested, but still has left the central bank with discretion to deal with unforeseen events in the economy. 
Disadvantages. Given the success of the "just do it" strategy, a natural question to ask is why countries such as the United States should consider other monetary policy strategies which would change something that has already worked well, especially given the inability to know what types of challenges will confront monetary policy in the future: In other words, "If it ain't broke, why fix it?" The answer is that the "just do it" strategy has some disadvantages that may cause it to work less well in the future.

An important disadvantage of the "just do it" strategy is that it may not be very transparent. This may create financial and economic uncertainty that makes the economy function less efficiently. Furthermore, because of the lack of transparency, a "just do it" strategy may leave the central bank relatively unaccountable. As a result, the central bank is more susceptible to the time-inconsistency problem, whereby it may pursue short-term objectives at the expense of long-term ones. Furthermore, because of the lack of transparency and accountability, it may be harder for the central bank to lock in low inflation: the absence of a nominal anchor makes inflation expectations more susceptible to rise when there are negative supply or other shocks to the economy, thus making higher inflation likely.

The most important disadvantage of the "just do it" strategy is that it depends on individuals: that is, the chairman or governor of the central bank and the composition of the monetary board that participates in monetary policy decisions. Having forward-looking individuals who sufficiently value price stability can produce excellent policies. For example, Chairman Greenspan and other Federal Reserve officials continually have expressed a strong preference for low, steady inflation, and their comments about stabilization policies have prominently featured consideration of the long-term inflation implications of their policies.

The problem with a strategy that is based on individuals is that the individuals can change. If the chairman or other members of the FOMC were replaced by people who were less committed to price stability as an important goal for the Fed, the Fed could conceivably return to policies that created the high inflation of the 1970s. Moreover, our earlier discussion suggested that the time-inconsistency problem and a bias towards high inflation may not arise in the central bank, but may instead come from pressures exerted by politicians. Thus, for example, even if similar individuals to those currently on the FOMC were in charge of monetary 
policy, a different political environment might push them to pursue more expansionary policies. Indeed, in recent years the executive branch of the U.S. government has rarely criticized the Federal Reserve for its policies, and this may have contributed to the success the Federal Reserve has had in controlling inflation.

One way to encourage monetary policy to focus on long-run objectives such as price stability is to grant central banks greater independence. In the view of many observers, politicians in a democratic society are shortsighted because they are driven by the need to win their next election. With their focus on the upcoming election, they are unlikely to focus on long-run objectives, such as promoting a stable price level. Instead, they will tend to seek shortrun objectives, like low unemployment and low interest rates, even if the short-run objectives may have undesirable long-run consequences. With a grant of independence, central banks are able to communicate to the public that they will more likely be concerned with long-run objectives and thus be a defender of price stability, particularly if there is a legislated mandate for the pursuit of price stability.

Recent evidence seems to support the conjecture that macroeconomic performance is improved when central banks are more independent. When central banks in industrialized countries are ranked from least legally independent to most legally independent, the inflation performance is found to be the best for countries with the most independent central banks. ${ }^{16}$ However, there is some question as to whether causality runs from central bank independence to low inflation, or rather, whether a third factor is involved such as the general public's preferences for low inflation that create both central bank independence and low inflation. ${ }^{17}$

Central bank independence may have much to recommend it and, while there is a current trend to greater independence of central banks, this independence may still not be enough to produce sufficient commitment to the goal of price stability. This is why, despite the success of a "just do it" strategy for monetary policy, it may be very worthwhile to institutionalize the commitment to price stability and formalize the strategy by making explicit a commitment to a nominal anchor as with inflation targeting.

\footnotetext{
${ }^{16}$ See Alesina and Summers (1988), Cukierman (1992), and Fischer (1994) among others.

${ }^{17}$ Posen (1995).
} 


\section{IV. \\ Conclusions}

What we have seen over the last thirty years is a growing consensus that price stability should be the overriding, long-term goal of monetary policy. With this mandate, the key question for central bankers is what strategies for the conduct of monetary policy will best help to achieve this goal. This paper discusses four basic strategies: exchange rate pegging, monetary targeting, inflation targeting, and the "just do it" strategy of preemptive monetary policy with no explicit nominal anchor. Although none of these strategies dominates the others for every country in the world, we do see that some strategies may make more sense under certain circumstances than others. For example, the breakdown of the relationship between monetary aggregates and goal variables, such as nominal spending or inflation, implies that monetary targeting is unlikely to be a viable option in the United States for the foreseeable future. On the other hand, exchange rate pegging is not even an alternative for the United States because it is too large a country to anchor to its currency to any other. Thus, a lively debate is worth pursuing over whether the United States would be better served by the Federal Reserve continuing to operate as it has, or whether it would be better for it to switch to an inflation targeting regime with its increased transparency and accountability.

For some other countries that are both small and where government institutions have relatively low credibility, a stronger commitment mechanism may be required to keep inflation under control. In these circumstances, a strategy of exchange-rate pegging, particularly with a strict commitment mechanism such as a currency board, might be more attractive. However, as this paper makes clear, such a strategy is not without its dangers and may require measures to protect the financial sector from adverse shocks.

The study of strategies to control inflation is one of the most important that monetary economists encounter. Indeed, this paper is just part of a larger project on this topic that has been under way under my direction at the Federal Reserve Bank of New York. 


\section{References}

Akerlof, George, William Dickens, and George Perry, "The Macroeconomics of Low Inflation", Brookings Papers on Economic Activity, 1996:1: 1-59.

Alesina, Alberto, and Lawrence H. Summers. 1993. "Central Bank Independence and Macroeconomic Performance: Some Comparative Evidence." Journal of Money, Credit, and Banking 25: 151-62.

Bailey, Martin J. 1956. "The Welfare Cost of Inflationary Finance." Journal of Political Economy 64: 98-110.

Barro, Robert J., and David B. Gordon. 1983. "A Positive Theory of Monetary Policy in a Natural Rate Model.” Journal of Political Economy 91: 589-610.

Bernanke, Ben S. and Frederic S. Mishkin. 1992. "Central Bank Behavior and the Strategy of Monetary Policy: Observations from Six Industrialized Countries," NBER Macroeconomics Annual 1992: 183-228.

Bernanke, Ben S. and Frederic S. Mishkin. 1997. "Inflation Targeting: A New Framework for Monetary Policy?” Journal of Economic Perspectives forthcoming.

Briault, Clive. 1995. "The costs of inflation." Bank of England Quarterly Bulletin 35 (February): 33-45.

Bruno, Michael. 1991. "High Inflation and the Nominal Anchors of an Open Economy," Princeton University, International Finance Section, Essays in International Finance No. 183, June 1991. 
Calvo, Guillermo. 1978. "On the Time Consistency of Optimal Policy in the Monetary Economy." Econometrica 46: 1411-28.

Cecchetti, Stephen. 1995. "Inflation Indicators and Inflation Policy," in Ben Bernanke and Julio Rotemberg, eds., NBER Macroeconomics Annual.

Clarida, Richard and Mark Gertler. 1997. "How the Bundesbank Conducts Monetary Policy." in Christina D. Romer and David H. Romer, eds., Reducing Inflation: Motivation and Strategy. Chicago: University of Chicago Press: $363-406$.

Cukierman, Alex. 1992. Central Bank Strategy, Credibility, and Independence: Theory and Evidence. Cambridge, Massachusetts:The MIT Press.

Debelle, Guy and Stanley Fischer. 1994. "How Independent Should a Central Bank Be?” In Jeffrey Fuhrer, ed., Goals, Guidelines, and Constraints Facing Monetary Policymakers. Boston: Federal Reserve Bank of Boston..

English, William B. 1996. "Inflation and Financial Sector Size." Mimeo, Board of Governors of the Federal Reserve System, April.

Estrella, Arturo and Frederic S. Mishkin. 1996. "Is There a Role for Monetary Aggregates in Conduct of Monetary Policy." Paper presented at the Monetary Policy and Financial Markets Conference in Gerzensee, Switzerland, October.

Feldstein, Martin. 1997. "The Costs and Benefits of Going from Low Inflation to Price Stability," in Christina D. Romer and David H. Romer, eds., Reducing Inflation: Motivation and Strategy. Chicago: University of Chicago Press: 123-156.

Fischer, Stanley. 1993. "The Role of Macroeconomic Factors in Growth.” Journal of 
Monetary Economics 32:485-512.

1994. "Modern Central Banking," in Forest Capie, Charles Goodhart, Stanley Fischer and Norbert Schnadt, eds. The Future of Central Banking: The Tercentenary Symposium of the Bank of England. Cambridge University Press: Cambridge, England and New York: 262-308.

Friedman, Benjamin M. 1995. "The Rise and Fall of Money Growth Targets As Guidelines for U.S. Monetary Policy." Mimeo, Bank of Japan Conference, October.

Friedman, Benjamin M. and Kenneth N. Kuttner. 1993. "Another Look at the Evidence on Money-Income Causality." Journal of Econometrics 57: 189-203.

Friedman, Benjamin M. and Kenneth N. Kuttner. 1996. "A Price Target for U.S. Monetary Policy? Lessons from the Experience with Money Growth Targets.” Brookings Papers on Economic Activity forthcoming.

Friedman, Milton. 1968. "The Role of Monetary Policy." American Economic Review 58: $1-17$.

Friedman, Milton. 1977. "Nobel Lecture: Inflation and Unemployment." Journal of Political Economy 85: 451-72.

Goodhart, Charles and Jose Vinals. 1994. "Strategy and Tactics of Monetary Policy: Examples from Europe and the Antipodes," in Jeffrey Fuhrer, ed., Goals, Guidelines, and Constraints Facing Monetary Policymakers, Federal Reserve Bank of Boston.

Groshen, Erica L. and Mark E. Schweitzer. 1996. "The Effects of Inflation on Wage 
Adjustments in Firm-Level Data: Grease or Sand?” Federal Reserve Bank of New York Staff Reports, January 1996, no. 9.

Haldane, Andrew G. 1995. Targeting Inflation. Bank of England: London.

Hall, Robert E. and N. Gregory Mankiw. 1994. "Nominal Income Targeting," in N.G. Mankiw, ed., Monetary Policy, Chicago: U. of Chicago Press for the NBER.

Hess, Gregory D. and Charles S. Morris. 1996. "The Long-Run Costs of Moderate Inflation." Federal Reserve Bank of Kansas City Economic Review, Second Quarter 1996, 71-88.

Jonung, Lars. 1979. "Kurt Wicksell's Norm of Price Stabilization and Swedish Monetary Policy in the 1930s, "Journal of Monetary Economics, 5: 459-96.

Judson, Ruth and Athanasios Orphanides. 1996. "Inflation, Volatility and Growth." Mimeo, Board of Governors of the Federal Reserve System, May.

Kydland, Finn E., and Edward C. Prescott. 1977. "Rules Rather Than Discretion: The Inconsistency of Optimal Plans.” Journal of Political Economy 85: 473-91

Leiderman, Leonard and Lars E. O. Svensson, eds. 1995. Inflation Targets. Centre for Economic Policy Research, London.

Lucas, Robert E., Jr. 1976. "Econometric Policy Evaluation: A Critique." Journal of Monetary Economics, Supplementary Series 1, no. 2: 19-46.

McCallum, Bennett T. 1995. "Two Fallacies Concerning Central-Bank Independence." American Economic Review 85 (May): 207-11. 
McCallum, Bennett T. 1996. "Inflation Targeting in Canada, New Zealand, Sweden, the United Kingdom, and in General," NBER Working Paper no. 5597, May.

Mishkin, Frederic S. 1996. "Understanding Financial Crises: A Developing Country Perspective," in Michael Bruno and Boris Pleskovic, eds., Annual World Bank Conference on Development Economics 1996 (World Bank: Washington D.C. 1996): 2962.

Mishkin, Frederic S. and Adam Posen. 1997. "Inflation Targeting: Lessons from Four Countries," Federal Reserve Bank of New York, Economic Policy Review, forthcoming.

Obstfeld, Maurice and Kenneth Rogoff. 1995. "The Mirage of Fixed Exchange Rates," Journal of Economic Perspectives 9 (Fall): 73-96.

Posen, Adam S. 1995. "Central Bank Independence and Disinflationary Credibility? A Missing Link?” Federal Reserve Bank of New York Staff Reports, May 1995, no. 1.

Samuelson, Paul A., and Robert M. Solow. 1960. "Analytical Aspects of Anti-inflation Policy.” The American Economic Review 50 (May): 177-194.

Sarel, Michael. 1996. "Nonlinear Effects of Inflation on Economic Growth." International Monetary Fund Staff Papers 43 (March): 199-215.

Stock, James H. and Mark W. Watson. 1989. "Interpreting the Evidence on Money-Income Causality." Journal of Econometrics 40: 161-182.

Taylor, John. 1985. "What Would Nominal GDP Targeting Do to the Business Cycle?" Carnegie-Rochester Conference on Public Policy, Amsterdam, North-Holland, 22, 61-84. 
Figure 1

Phillips Curve, 1948-1969

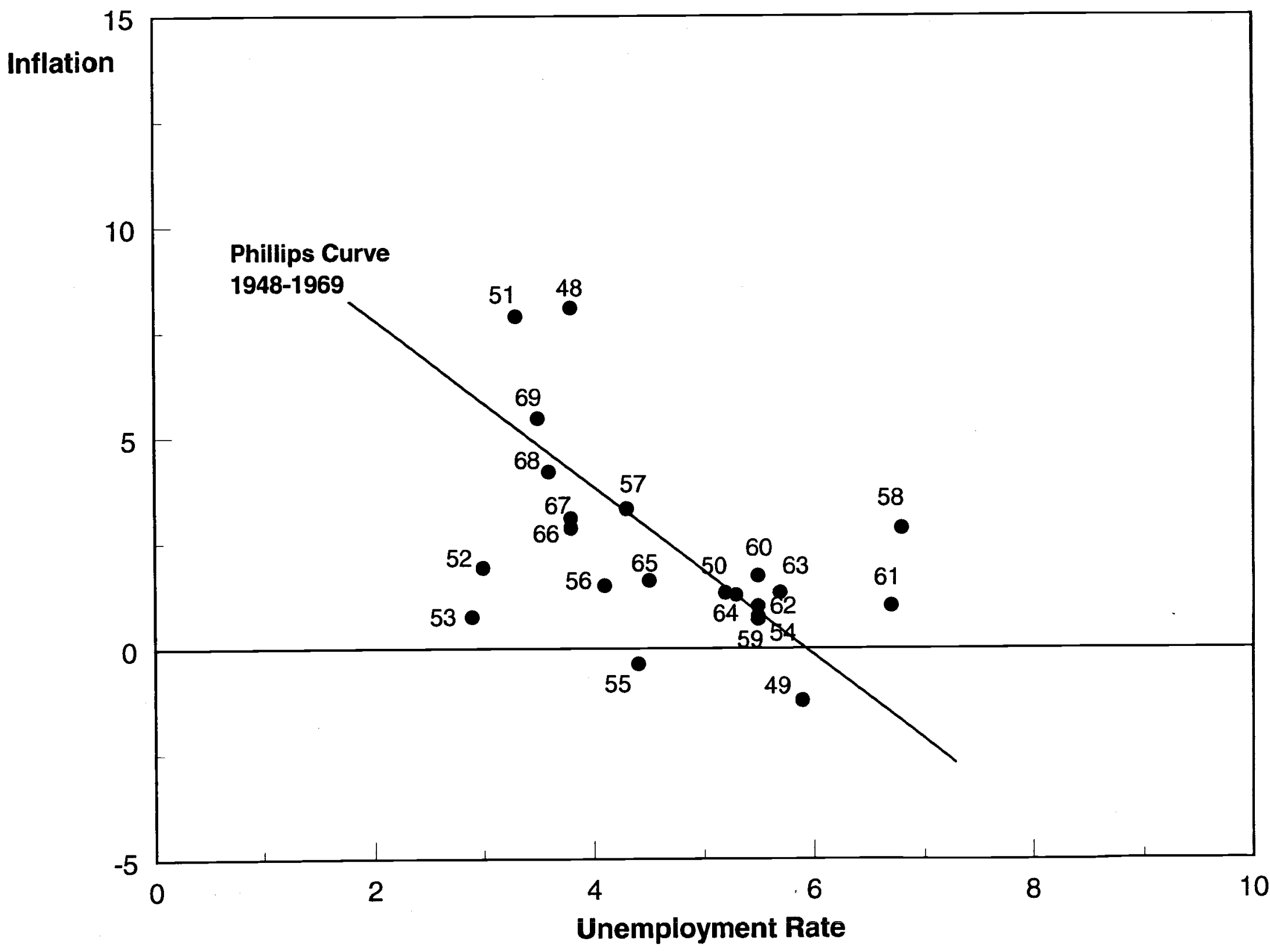

Source: Economic Report of the President 
Figure 2

Phillips Curve, 1948-1996

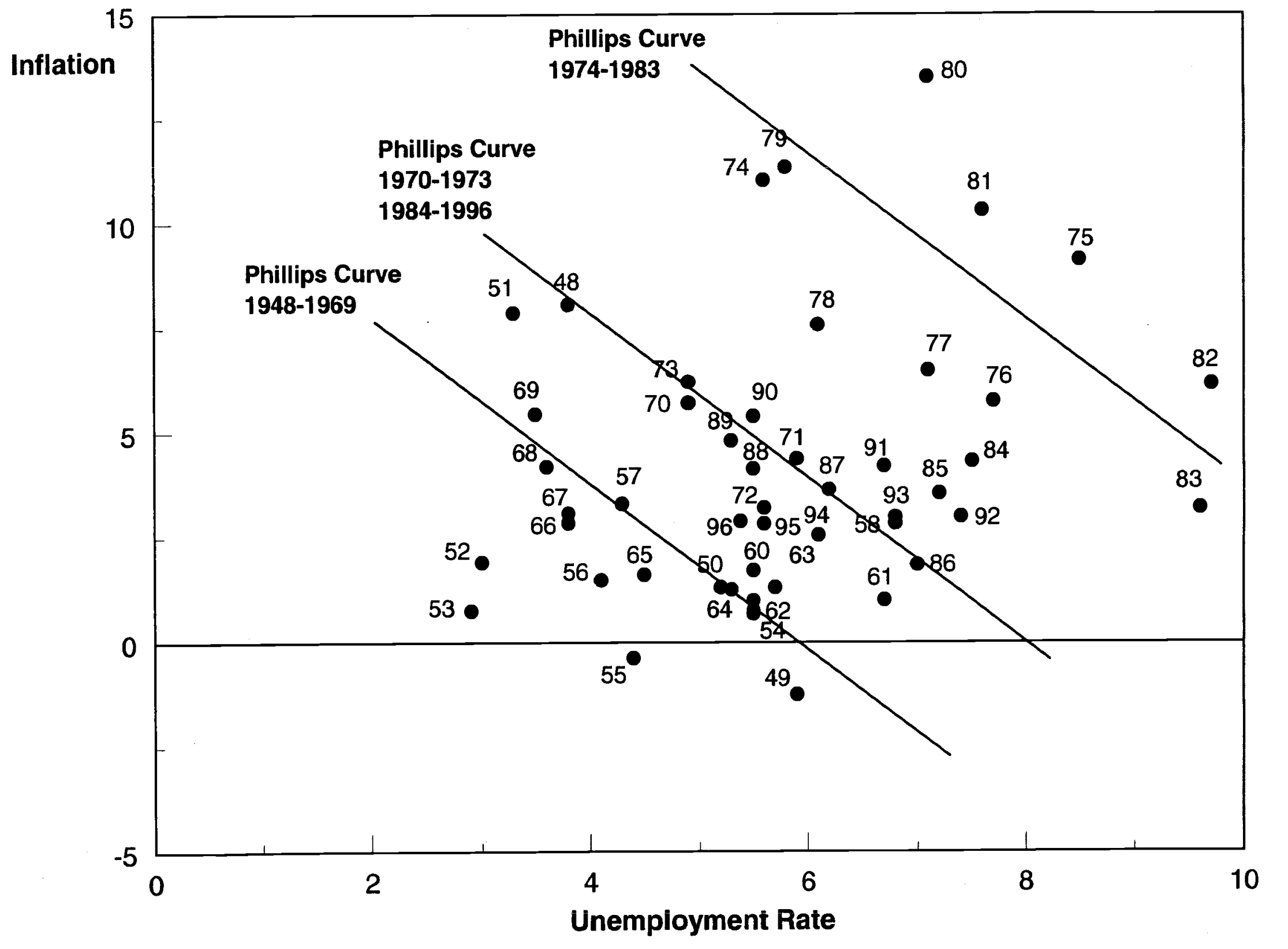




\section{Figure 3: \\ FRANCE \\ Economic Timeline}

GDP Growth and Unemployment Rate
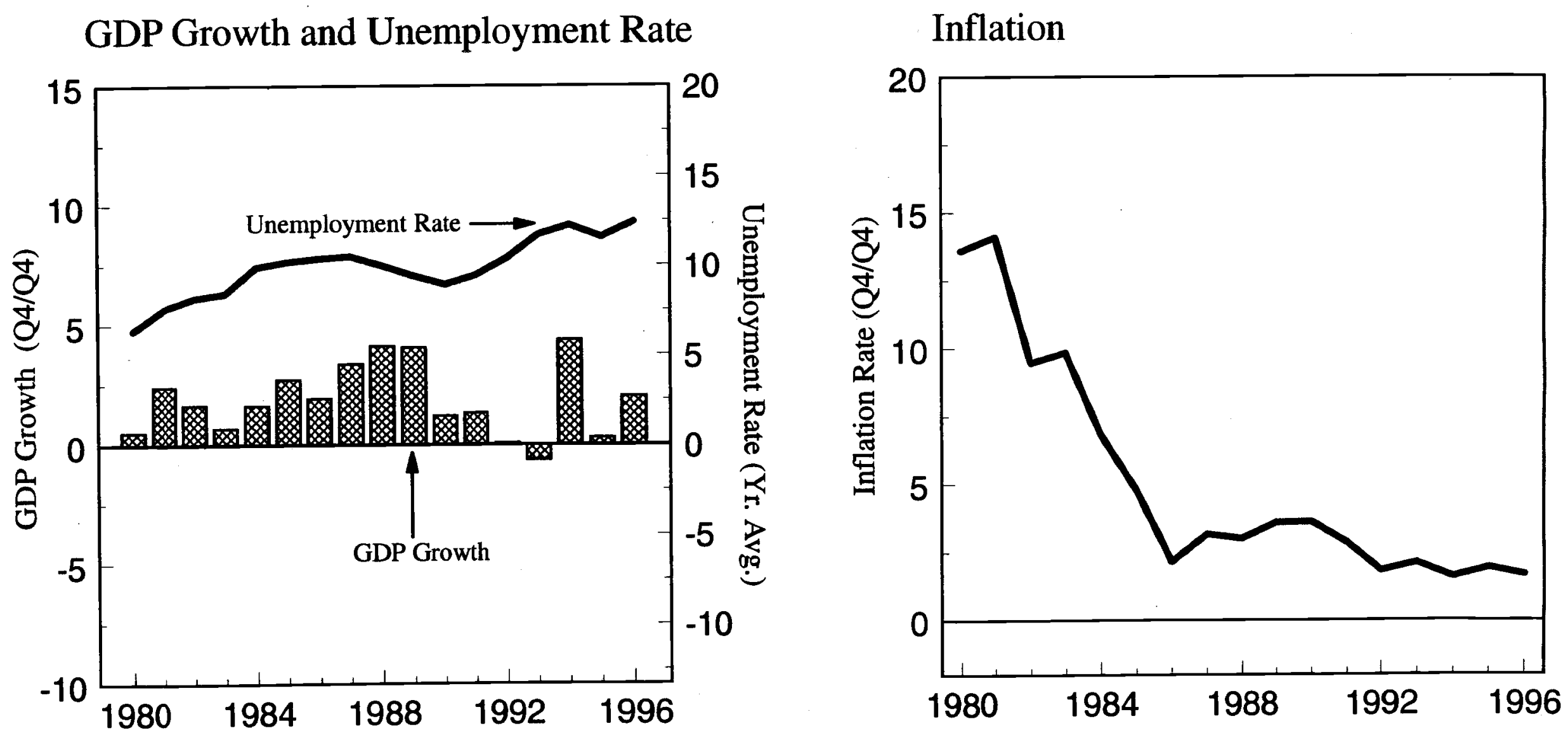

Source: Bank of International Settlements. 


\section{Figure 4: \\ GERMANY \\ Economic Timeline}

GDP Growth and Unemployment Rate

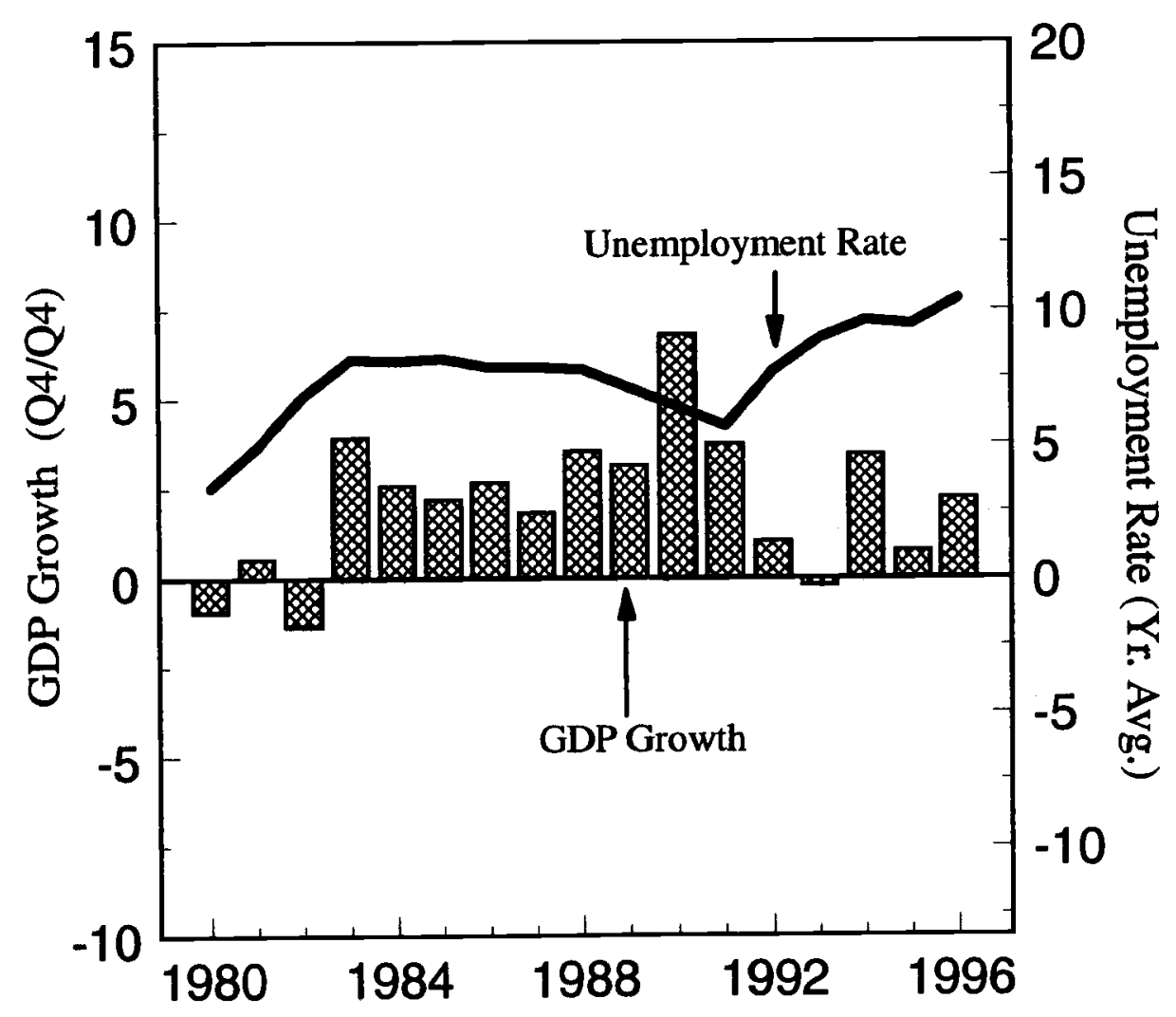

Inflation

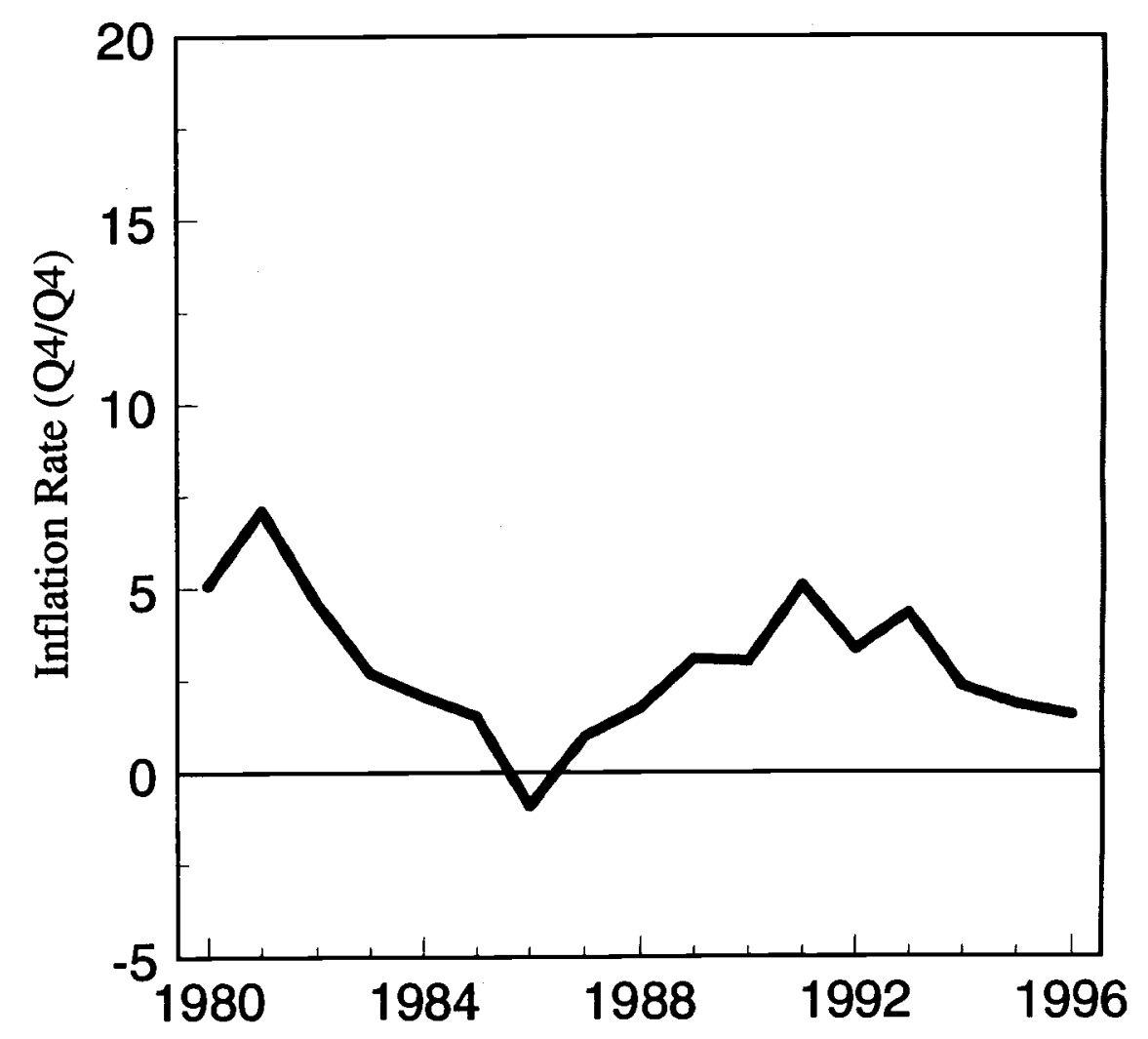

Source: Bank of International Settlements. 


\section{Figure 5: \\ UNITED KINGDOM \\ Economic Timeline}
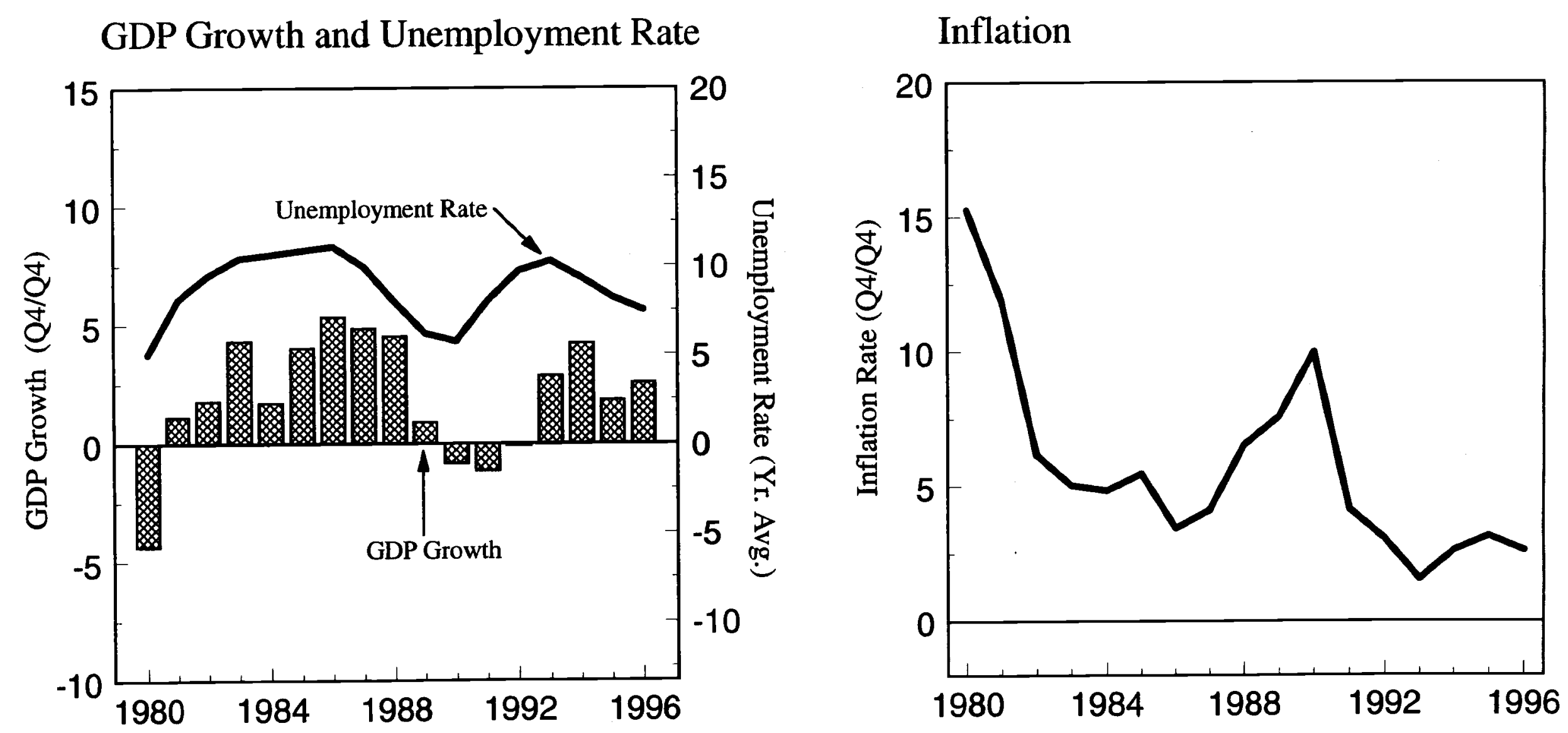

Source: Bank of International Settlements. 


\section{Figure 6: ARGENTINA \\ Economic Timeline}

GDP Growth and Unemployment Rate

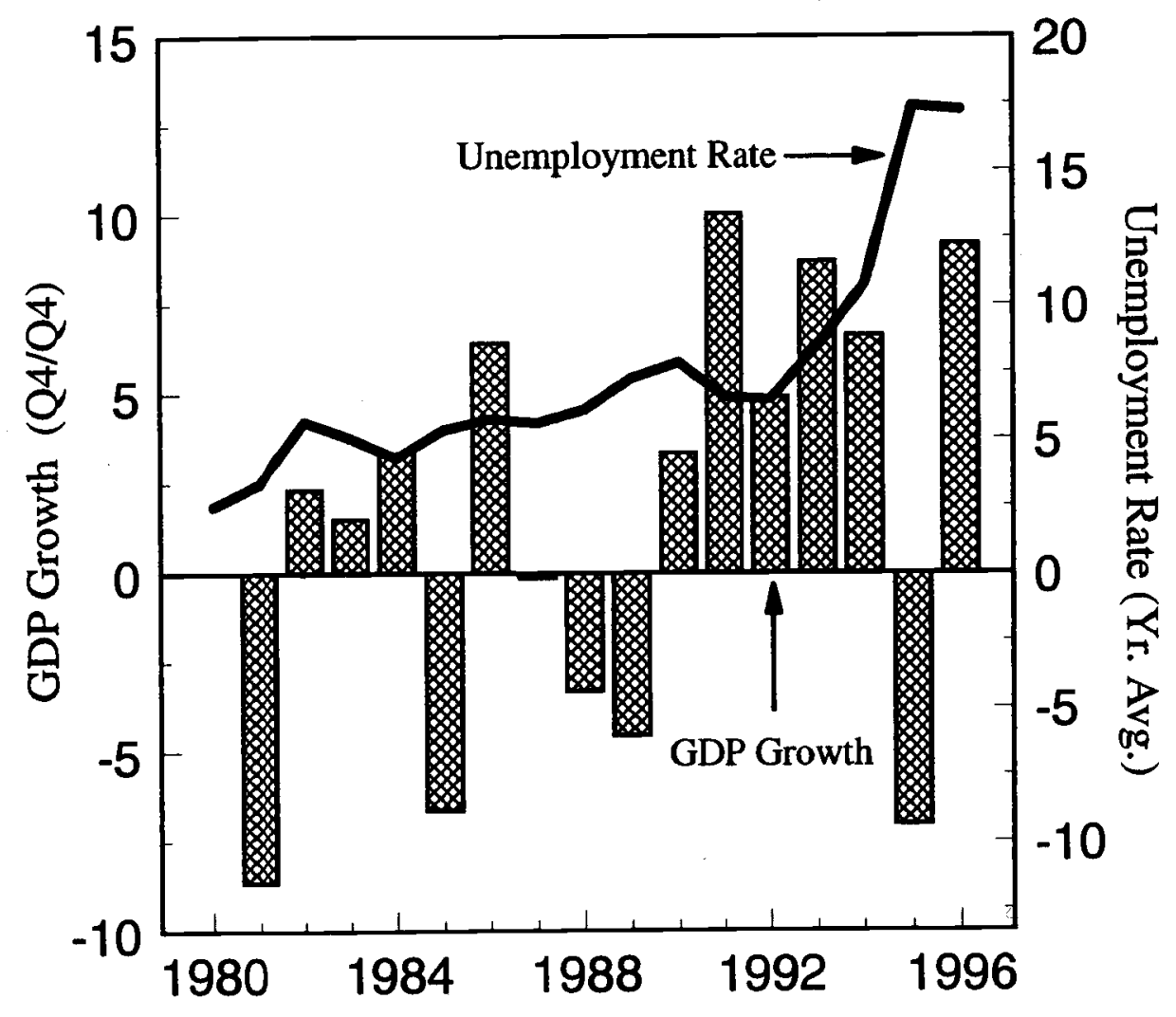

Inflation

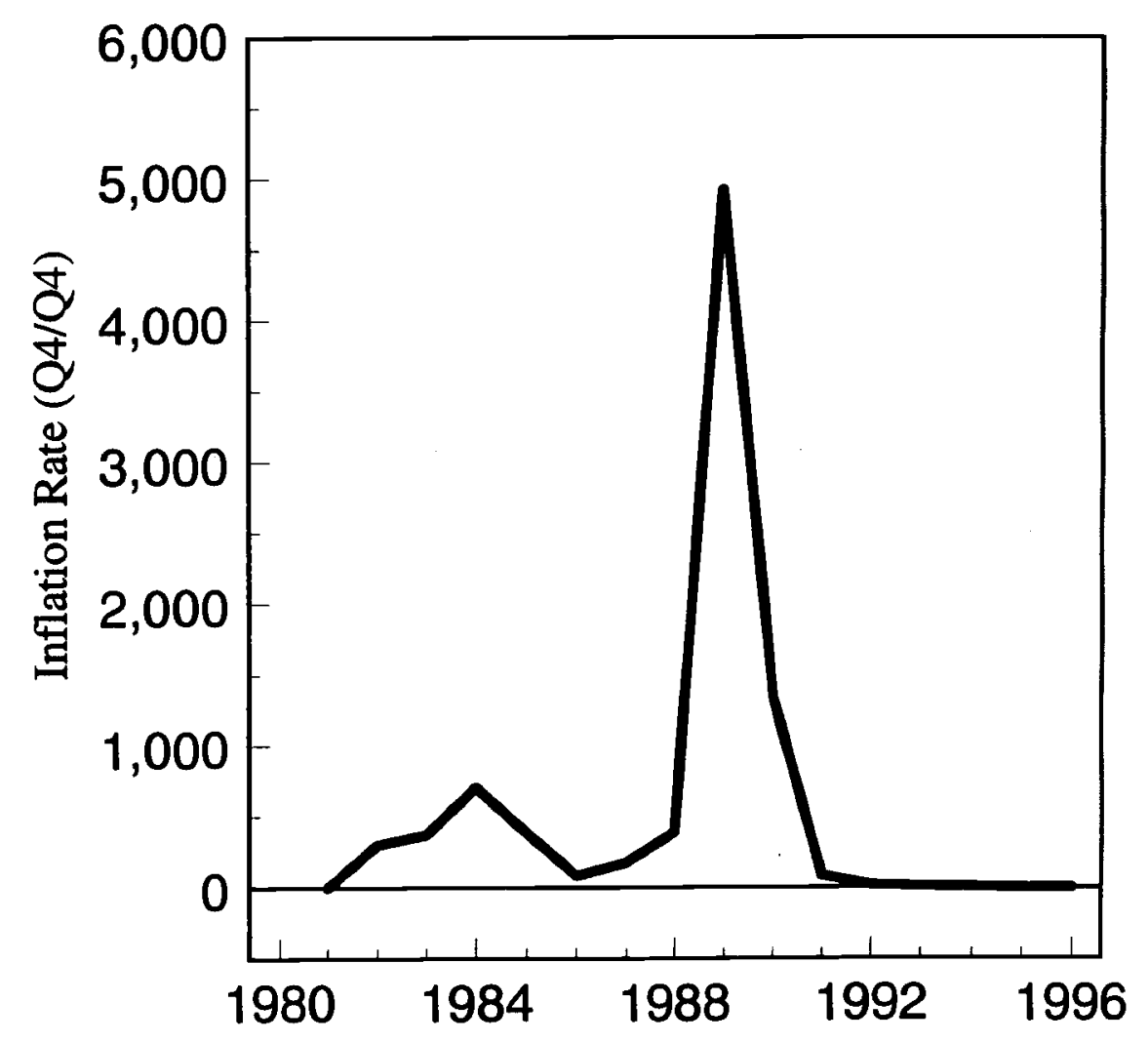

Source: Datastream. 


\section{Figure 7: \\ MEXICO \\ Economic Timeline}

GDP Growth and Unemployment Rate

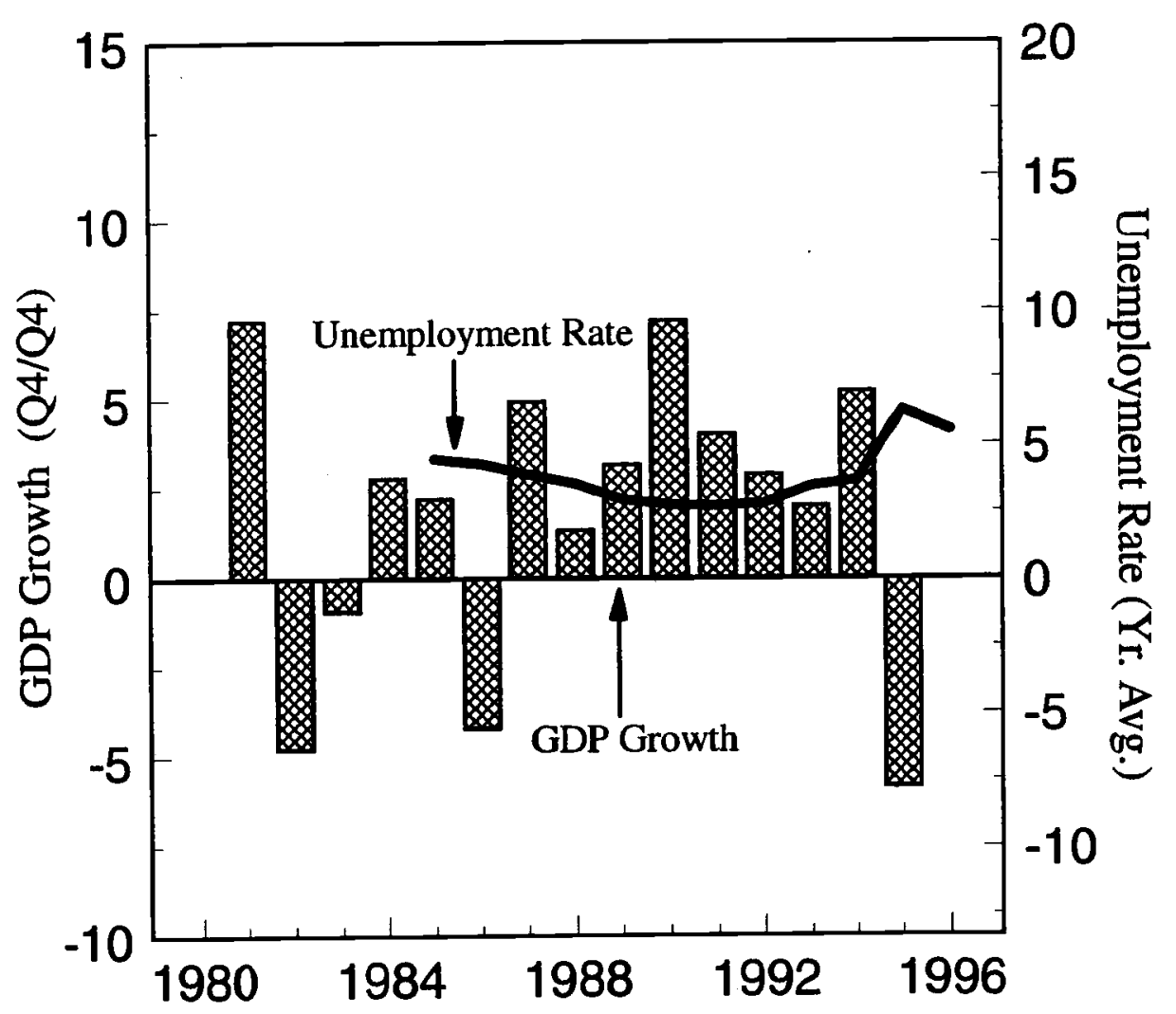

Inflation

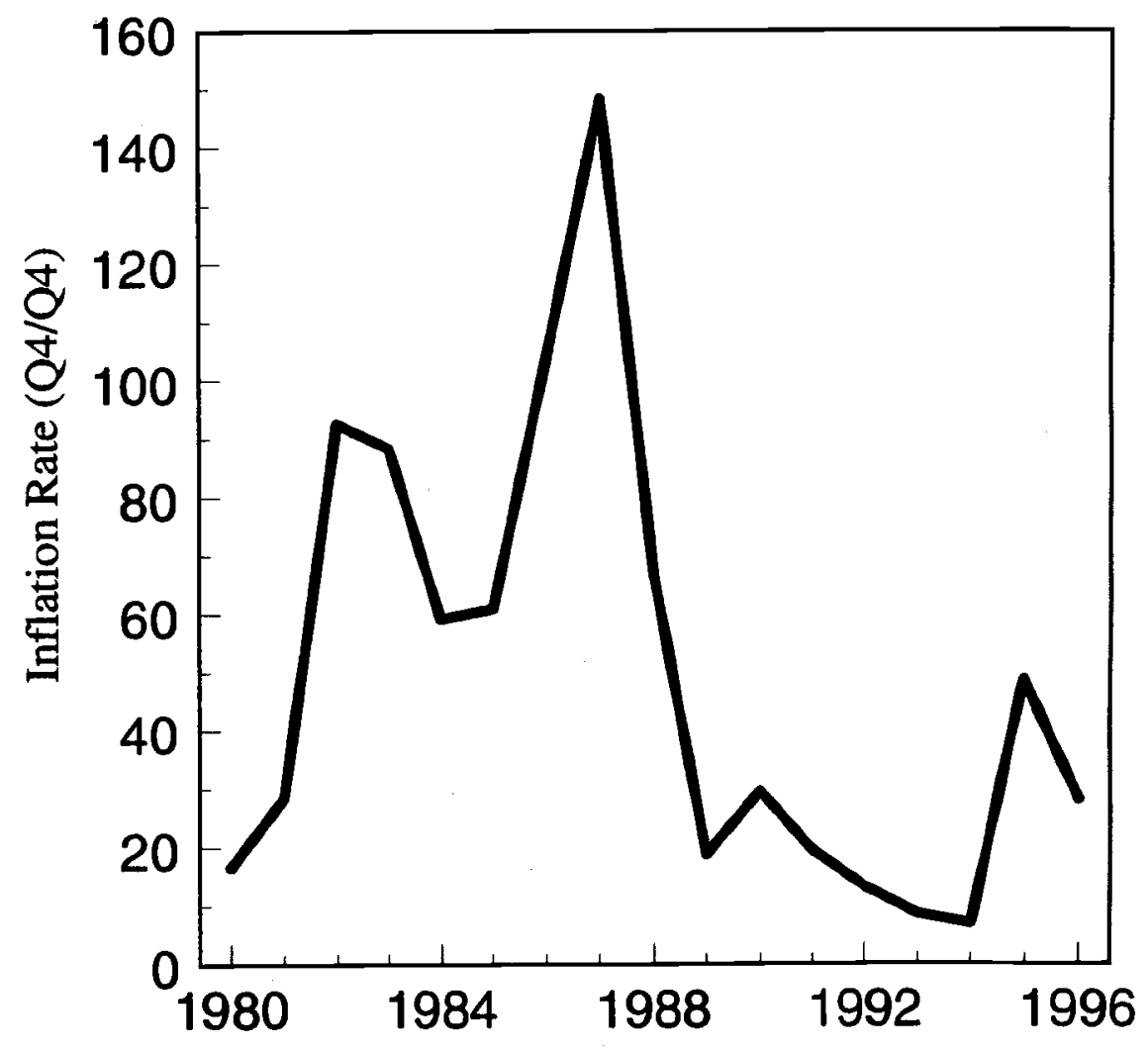

Source: Unemployment -- Datastream.

GDP and Inflation -- International Financial Statistics. 


\section{Figure 8:}

CANADA

\section{Economic Timeline}

GDP Growth and Unemployment Rate

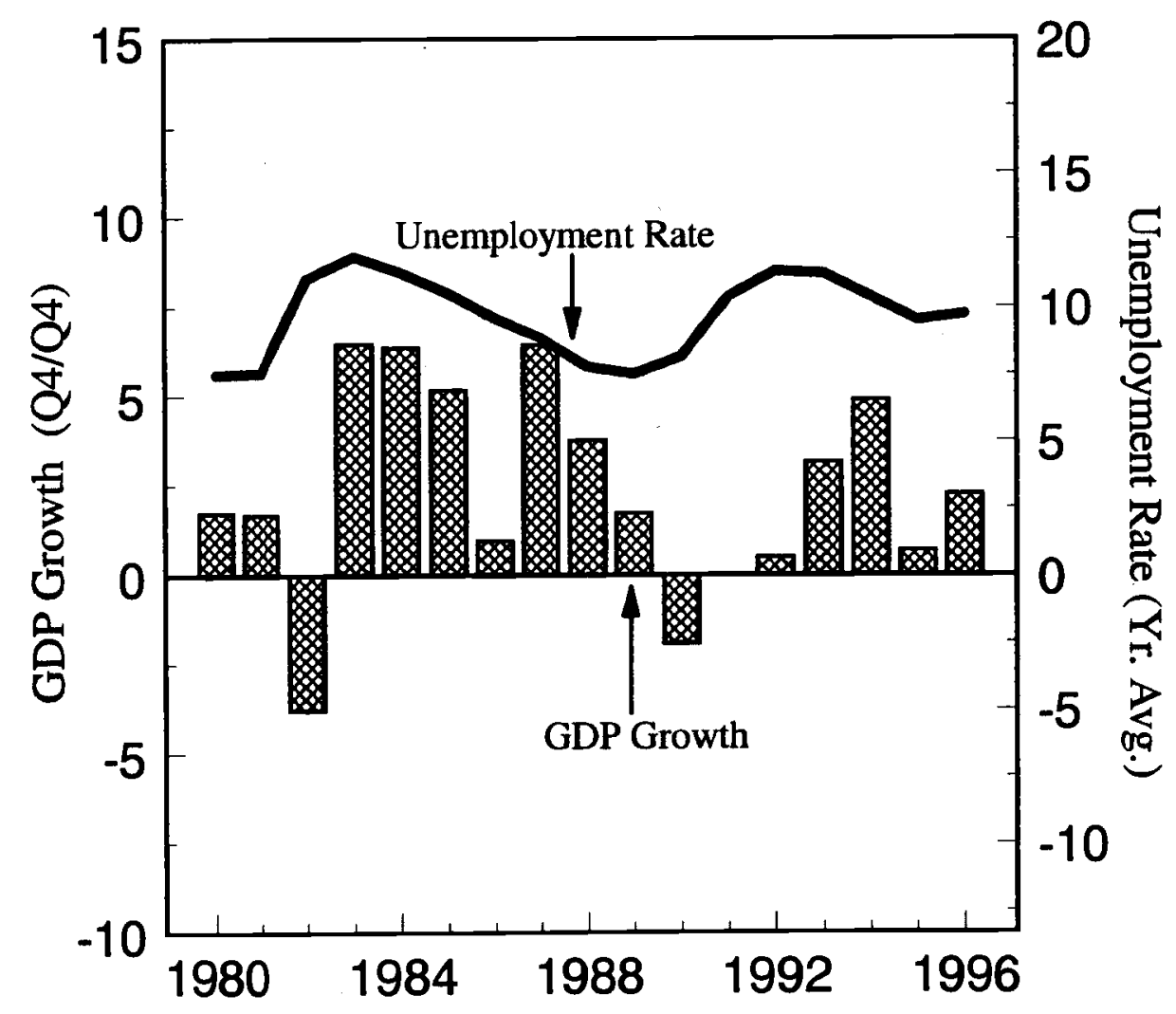

\author{
Inflation
}

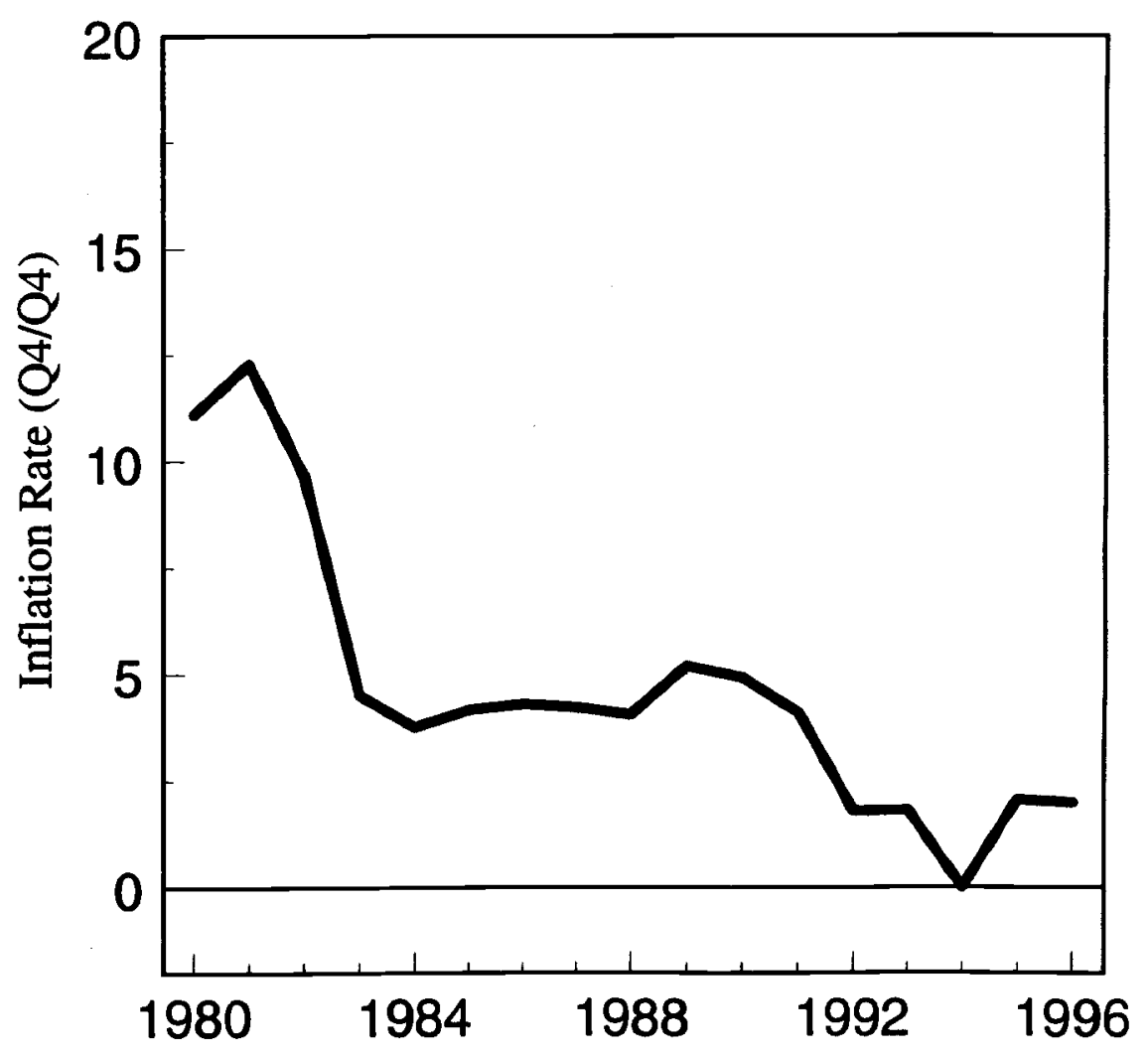

Source: Bank of International Settlements. 


\section{Figure 9: \\ NEW ZEALAND \\ Economic Timeline}

GDP Growth and Unemployment Rate

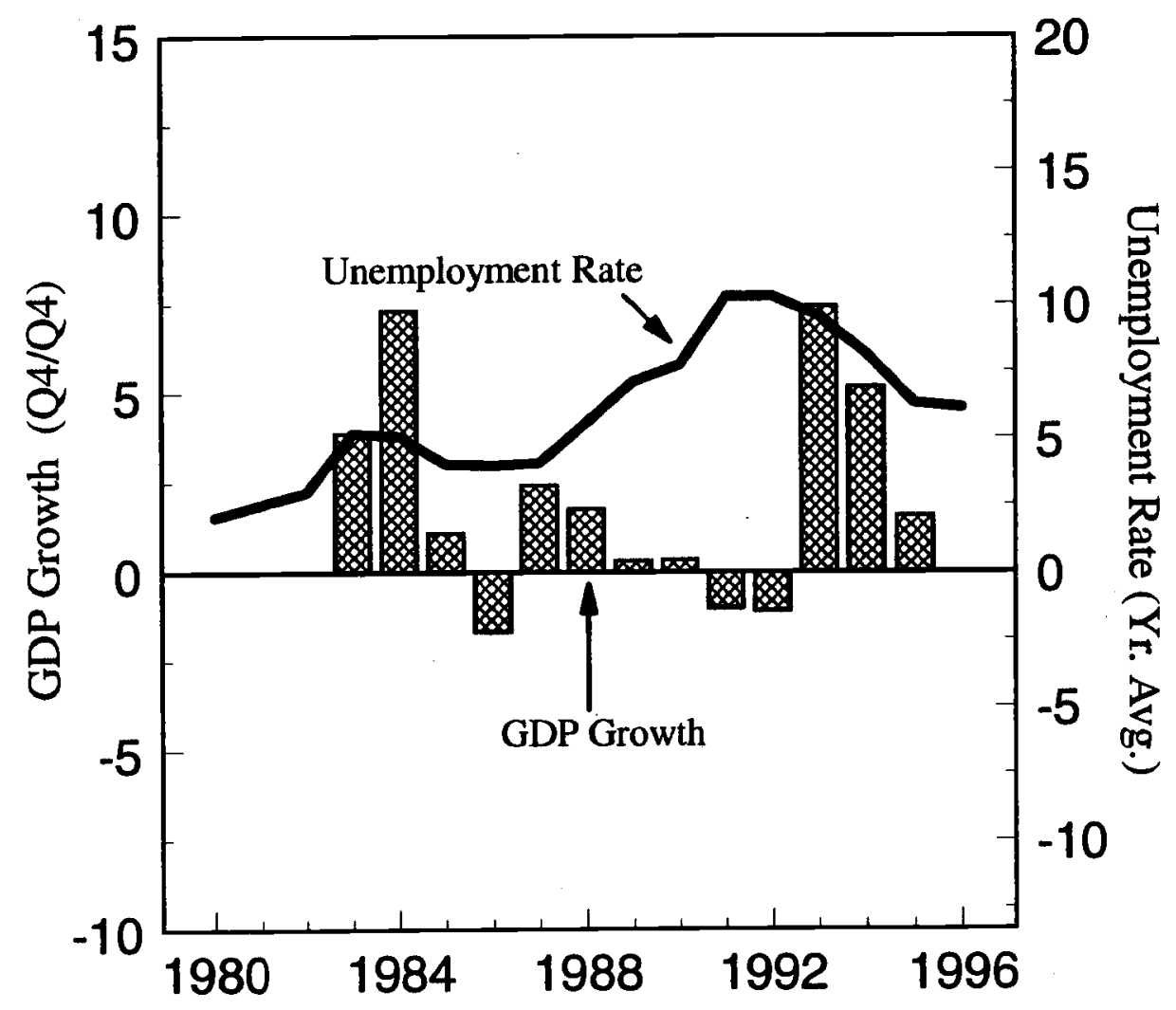

Inflation

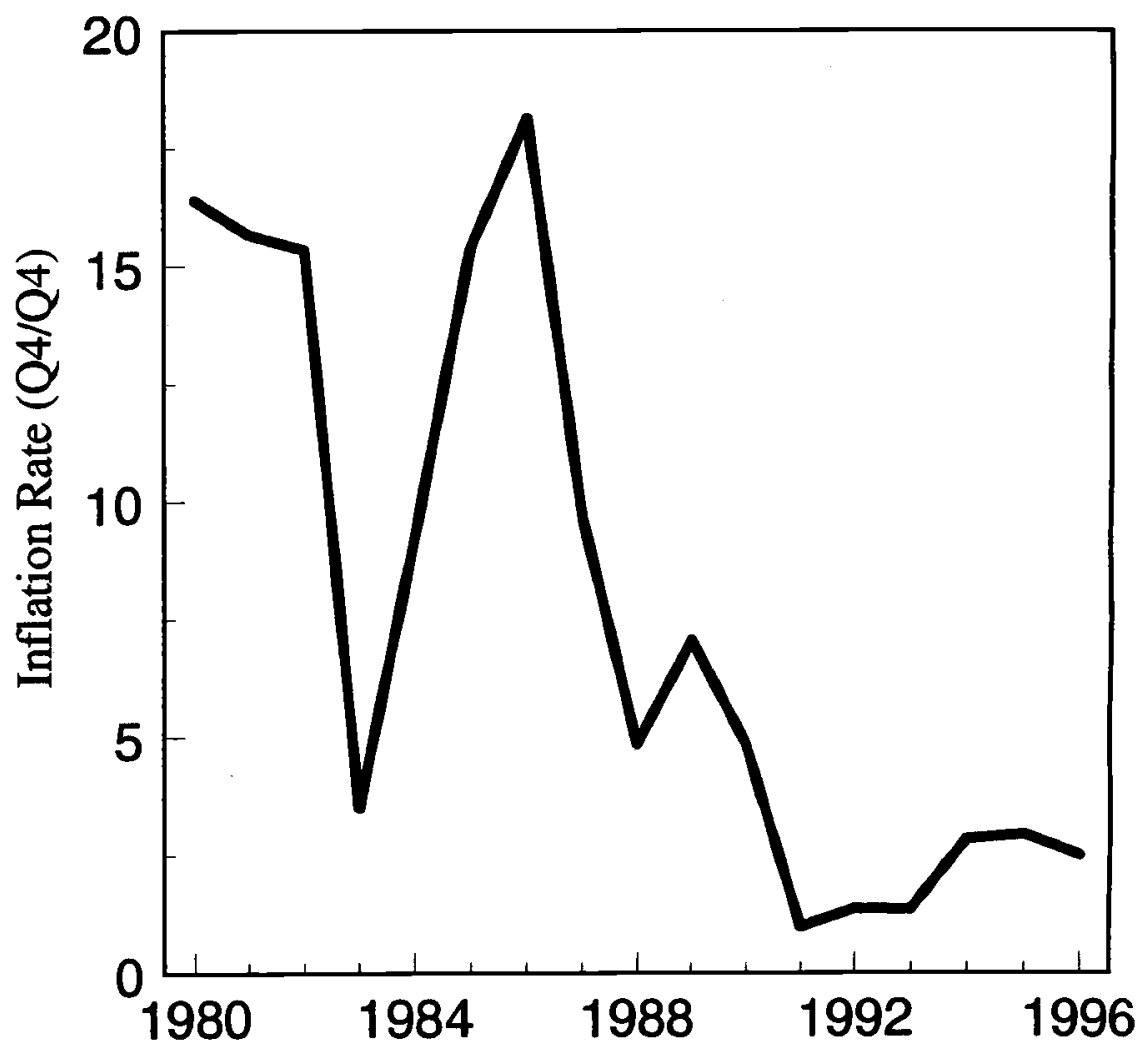

Source: Bank of International Settlements. 


\section{Figure 10: UNITED STATES \\ Economic Timeline}

GDP Growth and Unemployment Rate

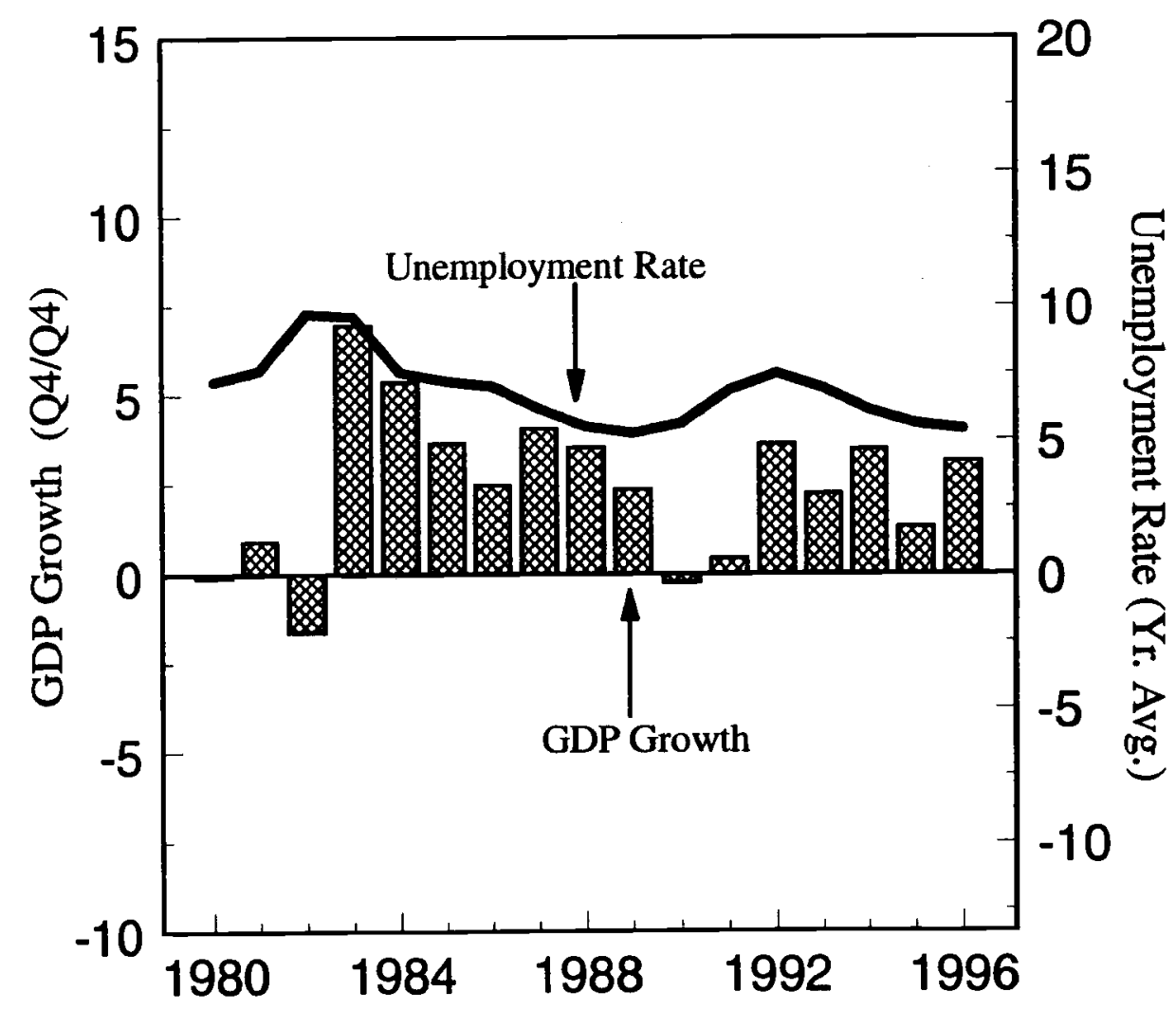

Inflation

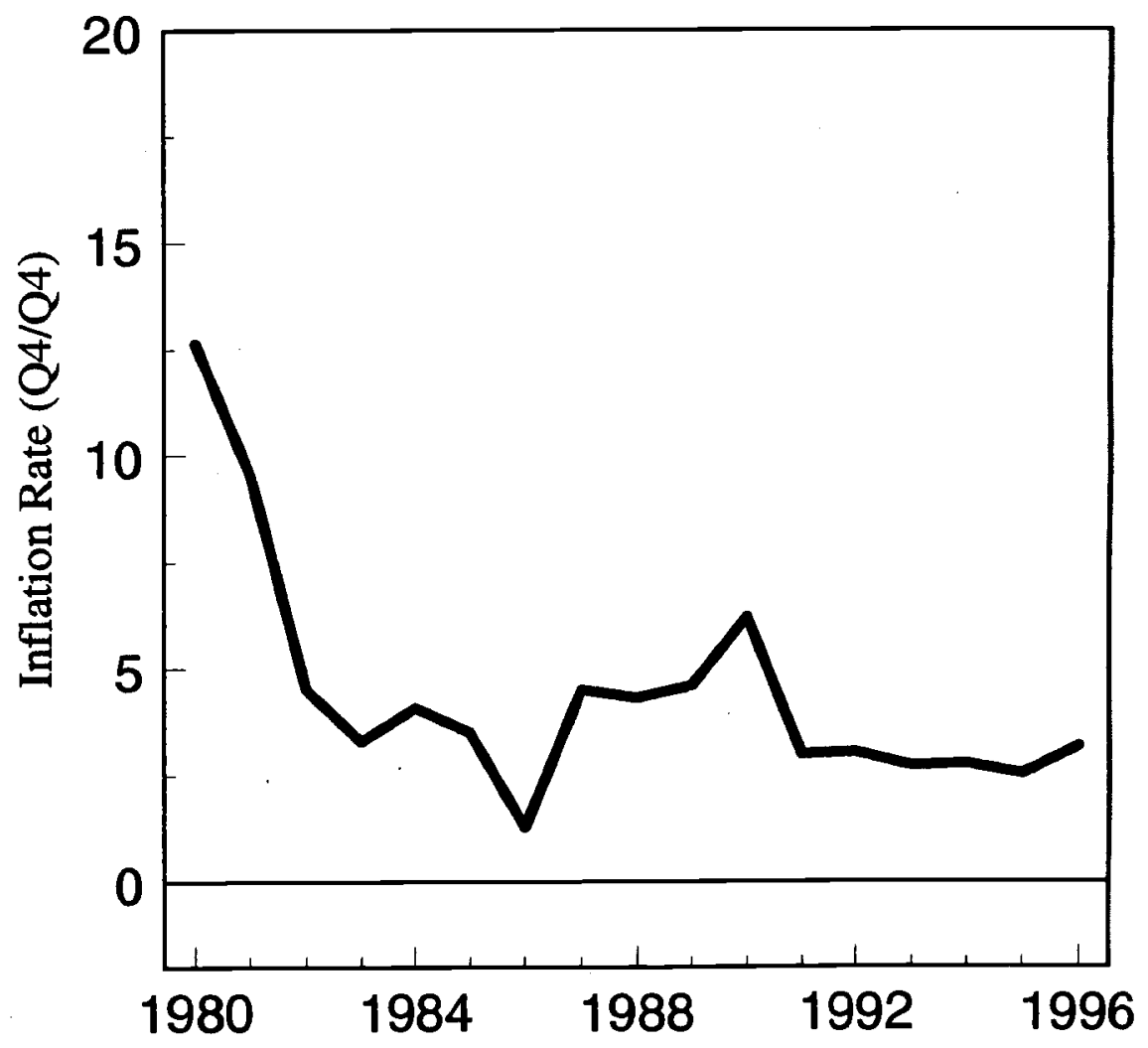

Source: Bank of International Settlements. 